\title{
Venture Capital Investment and the Performance of Entrepreneurial Firms: Evidence from China
}

\author{
Di Guo $^{\mathrm{a}^{*}} ;$ Kun Jiang $^{\mathrm{a}}$ \\ ${ }^{\text {a }}$ Faculty of Business and Economics, The University of Hong Kong, Pokfulam Road, Hong Kong
}

\section{Introduction}

Venture capital investment is one of the most effective ways to finance newly established innovative firms, which hardly have access to other types of external investment. Practitioners and researchers suggest that venture capitalists (VCs) not only provide funds, but also exert intensive monitoring efforts and provide value-added support to projects with growth potential. Thus, VCs differentiate themselves from traditional financiers in terms of efficiently dealing with profound information and uncertainty issues associated with the investment (Salhman, 1990; Gompers and Lerner, 2001). From this context emerge two questions on the role of VCs in the growth and R\&D activities of entrepreneurial firms: (1) Do VC-backed firms outperform nonVC-backed firms in terms of growth and innovation? (2) If so, can the performance of VCbacked firms be attributed to VCs' ability to choose better companies ex ante, or their capacity to monitor and help entrepreneurial firms to perform better after making an investment?

The impact of venture capital investment on entrepreneurial companies has attracted intensive interest from researchers in the past two decades. Kortum and Lerner (2000) find that based on industry-level data, venture capital activities significantly increase the propensity to patent inventions. Similarly, based on a survey of entrepreneurial firms in Silicon Valley, Hellmann and Puri (2000) report that more innovative firms have higher chances to be selected by VCs compared to imitators. Moreover, VC-backed firms introduce new products to the market faster than non-VC-backed firms do. Hellmann and Puri (2002) also reveal that VC intervention is important in the professionalization and development of young companies, particularly in the formulation of human resource policies and adoption of strategic management decisions. Puri and Zarutskie (2012) find that VC-backed firms grow more rapidly in scale compared to their non-VC-backed counterparts. Additionally, the authors report that VC-backed

${ }^{*}$ Corresponding author: Tel: +852 3917 1012; E-mail address: diguo@hku.hk 
firms are less likely to fail in the first four years after initially receiving venture investment. Chemmanur et al. (2011) examine the total factor productivity (TFP) of VC-backed and non-VCbacked firms using U.S. census data. The authors find that VC-backed firms outperform nonVC-backed ones in terms of TFP, and this outperformance is attributed to the ex-ante project screening and ex-post monitoring efforts of the VCs.

Studies have also focused on the role of venture capital investment in the initial public offerings (IPOs) of entrepreneurial firms. The findings, however, are mixed. Megginson and Weiss (1991) and Barry et al. (1990) find that VC-backed IPOs are less underpriced than nonVC-backed IPOs. Brav and Gompers (1997) further prove that when returns are equally weighted, VC-backed IPOs outperform non-VC-backed IPOs over a five-year period. However, Bradley and Jordan (2002) assert that after controlling for industry effects and underwriter quality, no difference exists in the underpricing of VC-backed and non-VC-backed IPOs. Moreover, after dealing with potential selectivity biases, Lee and Wahal (2004) point out that VC-backed IPOs are significantly more underpriced than non-VC-backed IPOs.

Although most existing studies have shown evidence that VC-backed firms generally outperform non-VC-backed firms, an important but under-investigated question remains: Are the performance differences between VC-backed and non-VC-backed firms caused by the ex-ante project selection or post-investment monitoring and support efforts of VCs? Filling this research gap enables us to understand the fundamental mechanism of venture capital investment; that is, whether VCs primarily contribute to firms by providing funds to better projects or fostering rapid growth (or by accomplishing both tasks).

The study of Chemmanur et al. (2011) is the first systematic analysis that detangles the screening and monitoring effects of VCs based on firm-level data. Using three different approaches to address the selection and identification issues, the authors confirm that in the United States, VCs not only choose to invest in firms with higher efficiency, but also help the firms to improve the efficiency after the investment is made. Moreover, the authors report that the improved efficiency is mainly contributed by the sales growth of the firms. Finally, the authors reveal that the efficiency improvement of the VC-backed firms is heterogeneous depending on the reputation of the VCs; that is, firms backed by VCs with higher reputation 
experience significantly higher post-investment efficiency improvement than those backed by VCs with lower reputation.

Our analysis attempts to extend the findings of Chemmanur et al. (2011) by examining the contribution of venture investment to entrepreneurial firms in China. Almost all previous studies on venture capital investment are based on data from developed economies. The issue of whether venture capital investment may also contribute to the performance and innovation of entrepreneurial firms in developing countries such as China, where the institutions are complicated and different from those in industrialized countries, has attracted less scrutiny. China, including Hong Kong, has been the second largest venture capital market in the world since 2001. ${ }^{1}$ Venture capital investment plays a major role in the startup of high-tech firms in China. Guo (2008) reports that over $62 \%$ of venture capital investment in China are in the hightech sectors. The impact of venture capital investment is also evident in the global market. From 2000 to 2010, over 500 VC-backed Chinese firms went public. In the first half of 2011, 207 of 339 new IPOs in 13 major global exchange markets were Chinese firms, 94 of which were VC-backed firms with proceeds of US $\$ 16.64$ billion. These figures suggest that the development of the venture capital market affects not only China's sustainable growth, but also the world's economic growth. However, systematic analysis on this market remains very limited.

The present study attempts to fill the existing gap by comparing the pre- and postinvestment performance and innovation of VC-backed and non-VC-backed firms in China using firm-level panel data in the period 1998 to 2007. The dataset we use is a census panel survey covering all manufacturing firms in China that generate annual revenue of over five million RMB. Matching VC-backed firms in China listed in the Venture Expert dataset to this panel dataset yields $258 \mathrm{VC}$-backed firms for the estimations.

We first examine whether VC-backed firms in China outperform their non-VC-backed counterparts in terms of profitability, labor productivity, sales growth, and R\&D activities. If VC-backed firms indeed outperform non-VC-backed firms, we further determine whether this outperformance is mainly caused by the project screening conducted by VCs or their monitoring efforts on the entrepreneurial firms after the investment is made. We then explore whether

\footnotetext{
${ }^{1}$ This ranking was calculated based on the data provided by the Asian Venture Capital Journals (2002).
} 
different VCs vary in project selection and ex-post monitoring activities by examining the performance of the firms backed by foreign venture capital firms (FVCFs) and those backed by domestic venture capital firms (DVCFs). Lastly, we determine whether different investment approaches have different effects on improving entrepreneurial firms by focusing on syndicated investment.

Our results indicate that VC-backed firms outperform non-VC-backed firms in several aspects, including profitability, labor productivity, sales growth, and R\&D investment. Moreover, similar to the findings of Chemmanur et al. (2011), we find this outperformance of VC-backed firms is caused by the project selection and ex-post monitoring efforts of VCs in China. That is, we find that VCs select firms with higher profitability, labor productivity, and sales growth, as well as firms investing more in R\&D activities. Additionally, the differences are significantly magnified after VC entry, with sales growth and R\&D investment as exceptions. After receiving investment from VCs, firms on average achieve higher ROS, ROE and labor productivity compared to non-VC-backed firms. No evidence, however, demonstrates that VC-backed firms experience magnified increase in terms of sales growth or R\&D investment compared to nonVC-backed ones after the investment is made.

We also find that different types of VCs vary in their project screening and value-added efforts. VCs in China are divided into two distinctive groups in terms of their organizational structure. Most FVCFs are incorporated off-shore and structured as limited partnerships. Conversely, the majority of DVCFs in China are structured as limited liability companies because limited partnership was illegal in China until June 2007. The governance of these two types of VCFs differs in a number of dimensions, such as incentive schemes, decision-making process, and compensation of investment professionals (Guo, 2008). We find that DVCs and FVCs choose better performing entrepreneurial firms. However, only firms backed by FVCs experience statistically significant improvements in profitability, productivity, and R\&D investment after the investment is made, thus suggesting that FVCs add more value than DVCs do.

Finally, we find that syndication may affect the performance of firms after the investment is made. Firms backed by syndicated VCs experience significantly magnified improvement in 
profitability, productivity, and R\&D investment after the investment is made compared to those backed by a single VC and non-VC-backed firms.

We further consider the potential identification issues. Although we empirically show that VCs invest in better performing companies, an alternative explanation is that VCs attract rather than select good firms. We address this issue by comparing the project assessment criteria identified by VCs with findings from our analysis. Consistent with our findings, interviews with 37 VCs in China suggest that the investment decision-making process is highly selective. In particular, financial performance and technological improvements are major concerns in investment decisions.

More importantly, to distinguish the ex-ante screening and ex-post monitoring effects of venture investment, we use two different methods for addressing the selection and identification concerns. First, we use the propensity score matching (PSM) methodology to match VC-backed firms with non-VC-backed firms by industry, location, and profitability of the firms prior to receiving venture financing to reduce the potential selection. We then compare the performance and $R \& D$ activities of the sampled firms and the matched firms. However, as stated by Chemmanur et al. (2011), the PSM approach may only deal with observable variables. VC involvement may be inflated by unobservable factors, such as market, entrepreneurial, and technological opportunities. We address this issue using two instrumental variables to identify whether the magnified performance of the VC-backed firms is driven by venture investment or certain unobservable variables. IPO is regarded as the most preferred exit approach for venture capital investment. IPO has long been highly regulated and restricted by the government in China (this topic is discussed in detail in Section 4). This exogenous factor may affect the decisions of VCs in the choice of entrepreneurial firms. We hence construct two instrumental variables to identify venture investment based on this information, namely, the number of IPO cases in Chinese stock markets, and IPO cases in both Chinese and overseas stock markets in the city where the firm is located one year before the venture investment is made. The results of the two-staged least square regressions confirm that the magnified performance improvements of VC-backed firms are indeed driven by venture investment. 
This paper is organized as follows. Section 2 provides an overview of the venture capital industry in China. Section 3 describes the data and sample. Section 4 presents the findings on the contributions of VCs to entrepreneurial firms, with the focus on distinguishing the effects of exante project screening and ex-post value-added efforts. Section 5 examines the value-added effects of DVCs and FVCs. Section 6 reports the findings on the value-added effects of syndicated and non-syndicated venture investment. Section 7 concludes this study.

\section{Venture Capital Industry in China}

\subsection{Overview}

Venture capital programs were initiated by the Chinese central government in the mid1980s as part of science and technology reform. With the transformation of China's centrally planned economy to a market-based system, the venture capital industry has experienced tremendous changes. In the first 10 years since the reform, the industry was merely a concept, with local and central governments as the major players. The first breakthrough did not occur until the late 1990s when venture fund sources were enriched. In 1996, large corporations, universities, and individuals were allowed to enter the industry for the first time. ${ }^{2}$ In 2001 , FVCFs finally gained legal recognition in China. ${ }^{3}$ Since then, an increasing number of mainstream FVCFs have entered China. However, the flow of new venture funds never exceeded US\$10 million before 2002 .

In 2005, new venture fund commitments transformed the venture capital industry in China. The amount of newly raised funds increased from US\$699 million in 2004 to US\$4.067 billion in 2005. The phenomenon was caused by a series of policy and legal changes related to private equity investment in 2004 and 2005. First, the right to private property was constitutionalized in $2004,{ }^{4}$ which encouraged external investors to make long-term investment.

\footnotetext{
${ }^{2}$ Individuals and corporations were prohibited from investing in venture capital funds before 1996. This restriction was removed with the passage of the law on Promoting the Industrialization of China's Technological Achievements in 1996. For the first time, this law legalized venture capital investment as a commercial activity, and permitted funds to be raised from diverse sources, including national or local governments, enterprises, organizations, and individuals.

${ }^{3}$ In 2001, the Ministry of Foreign Trade and Economic Cooperation (MoFTEC), together with the Ministry of Science and Technology (MoST) and the State Administration for Industry and Commerce (SAIC), issued the Provisional Regulations on the Establishment of Foreign Invested Venture Capital Investment Enterprises (the VC Regulations). By clarifying the registration requirements for foreign venture capital institutions, the regulation was the first effort by the Chinese government to confirm the legitimacy of FVCFs in China.

4 Amendments to the Constitution of the People's Republic of China were adopted at the Second Session of the Tenth National People's Congress of the People's Republic of China, and promulgated in 2004. For the first time, the constitution recognized private rights: " $[\mathrm{T}]$ he state protects the lawful rights and interests of the non-public sectors of the economy, including individual
} 
Second, regulations on foreign institutional investors have been substantially relaxed since 2003 when amendments to the Provisional Regulations for Establishment of Foreign-Invested Venture Capital Investment Enterprise were approved. ${ }^{5}$ Third, convertible security and preferred stock, which are often used by VCs to protect their investment from downside risks, were legalized in China in 2005. ${ }^{6}$ Lastly, after more than five years of discussion, the small and medium enterprise board of the Shenzhen Stock Exchange was opened in August 2004. The government has also substantially relaxed the approval procedures for Chinese firms to go IPO in overseas markets. These changes not only provided entrepreneurial firms with a greater chance to access public financial markets, but also significantly enriched the divestment channels of venture investment. These institutional changes, along with the strong economic growth of the country, attracted a wave of funds into the venture capital investment industry.

\subsection{Domestic and Foreign VCFs}

Currently, China is the second largest venture capital market in the world. Moreover, the venture capital market in China has attracted much interest from global players. The country is one of the most favored investment destinations of VCs in the world. ${ }^{7}$ The amount of investment made by FVCs accounted for over 65\% of the total investment in China between 2001 and 2008. ${ }^{8}$ However, due to regulatory restrictions, FVCFs and DVCFs evolved by following different historical paths, and consequently developed different organizational forms to cope with their unique institutional requirements. These two groups of VCFs differ in several aspects,

and private sectors of the economy. The state encourages, supports, and guides the development of the non-public sectors of the economy, and exercises supervision and control over the non-public sectors according to law."

5 According to the VC Regulations issued on August 29, 2001, FVCFs are allowed to register as qualified foreign institutional investors. However, FVCFs have to undergo a very strict and time-consuming approval process at various government agencies for registration. In addition, the rigid requirements for registered capital (at least US $\$ 20$ million; $15 \%$ of this amount must be paid within three months after the issue of the business license, and the remainder must be paid within three years whether or not attractive investment projects are available) serve as constraints for FVCFs. In January 2003, amendments to the VC Regulations were approved by SAIC, MOFTEC, STA, MoST, and SAFE. The revised version has clarified procedures in the registration of FVCFs and reduced the requirements for capital utilization. According to this revised version, capital from foreign investors should be exploited within five years. This revised version is significantly relaxed compared to the 2001 version that requires the utilization of capital within three years.

${ }^{6}$ Convertible security was not recognized in China until 2005 when the Interim Administrative Measures for the Startup Investment Enterprises was deliberated and approved by the State Council in September 2005, and promulgated by 10 different government agencies in November 2005. The regulations confirmed the legitimacy of using convertible security and preferred stock, among others.

${ }^{7}$ See the Global Trend in Venture Capital 2006 Survey released by Deloitte \& Touche LLP.

${ }^{8}$ This figure is calculated by the author based on the Annual Reports on Venture Capital Investment in China (Zero2IPO, 20012009). Accurate statistical data on venture capital investment prior to 2001 are unavailable. 
including ownership structure, decision-making process, intra-organizational information flow, compensation scheme, and fund sources.

DVCFs in China are mainly established as state-owned subsidiaries or spin-offs of local governments, large corporations, and prestigious universities. They are typically under the control of higher-level supervising organizations or large institutional shareholders. Almost all of the DVCFs are structured as limited liability companies because limited partnership was not legal in China as an organizational form until June 2007. Interviews with VCs show that top managers and investment professionals do not claim residual revenues because neither of them holds shares in DVCFs. They are normally compensated with fixed salaries plus bonuses. Bonuses are often determined by company-wide performance (Guo, 2008). In addition, limited companies are typically managed under a functional division structure with centralized decision making. All investment decisions are made by top managers based on information reported by investment managers. Furthermore, most executive managers in DVCFs are former government officers or SOE managers. They are typically appointed by government bureaus or their parent corporations. Very often, they do not have private equity financing expertise when they join DVCFs (Guo, 2008).

FVCFs have been struggling for legitimacy in China. Given the capital control regime of China, foreign institutional investors can hardly operate in the country. Regulations have been gradually relaxed since 2001. Foreign institutional investors may now legally invest and raise funds in China if they register as qualified foreign investment institutions (QFIIs). However, the threshold of the requirements for registration as QFIIs is too high that most FVCFs are unqualified. Facing rigorous capital control and other legal restrictions, FVCFs have been seeking effective vehicles to accommodate their investments in China. Before the mid-1990s, FVCFs mainly worked in joint ventures with domestic investors to overcome regulatory restrictions. They built relationships with the Chinese government and large SOEs to gain assistance in deal sourcing, project governance, and administrative protection, given the weak institutions in the country. However, the total capital inflow from FVCFs was small at the time, and their performance was far from satisfactory (Feng, 2004). 
With the benefit of accumulated experience, FVCFs have been exploring new ways to accommodate their investments in China since the late 1990s. The most popular approach is to invest in China using an offshore model; that is, FVCFs incorporate overseas and raise funds from international markets. Without registering in China, they establish representative offices to search, evaluate, and manage their investments in China. The registration of their portfolio companies follows a "round-trip" model. When an FVCF decides to invest in a project, it helps the founders to register an overseas holding company. Both the FVCF and the major founders of the company hold the majority shares in the holding company. The holding company then invests back in the original enterprise in mainland China, typically with $100 \%$ control. Hence, the corporate governance of both the FVCF and its portfolio company is less restricted by Chinese laws (Guo, 2008).

With the offshore model, the majority of FVCFs operating in China are structured as limited partnerships. Limited partnership is a dominant organizational form among VCFs in the United States. It provides strong incentives for VCs to maximize profits by aligning the interests of parties (Salhman, 1990; Gompers and Lerner, 1996). Interviews with VCs show that the corporate governance and operations of VCFs structured as limited partnerships in China are similar to those of limited partnership VCFs in the United States (Guo, 2008). Investors of venture funds are limited partners who contribute the majority capital, whereas VCs are general partners who contribute the minority capital. As general partners subject to unlimited liability, VCs are responsible for managing funds without the need for approval from limited partners. A typical "pay-for-performance" compensation structure is normally adopted, in which VCs charge $15 \%$ to $20 \%$ of the total profits as carrier interest and $1.5 \%$ to $3 \%$ of funds as annual management fees. Hence, the relationship between parties in limited partnerships is very "market-oriented." Furthermore, limited partnerships take a multi-functional division structure with decentralized decision making. Each VC typically has his/her own team to deal with nearly the entire process of an investment case, although the final investment decision is made based on the advice of an investment committee and the consensus of all general partners in the partnership. Limited partnerships are therefore flat organizations in which general partners work more independently compared to those in limited companies. 
FVCFs and DVCFs also differ in terms of fund sources and legal systems under which they are governed due to regulatory restrictions. FVCFs mainly raise funds from international markets. Similar to the case of VCFs in the United States, FVCFs in China source funds primarily from pension funds, insurance corporations, university endowments, and wealthy individuals. In China, however, laws prohibit pension funds, insurance corporations, and banks from investing in fields with high risks, such as venture capital funds. Hence, DVCFs source funds primarily from government agents, large corporations, and universities. With fund source limitations, DVCFs are much smaller in scale than FVCFs. In 2006, the average capital under each FVCF management was \$255 million, whereas it was only \$37 million for each DVCF (Zero2IPO, 2007). Furthermore, with the offshore strategy, the business activities of FVCFs and their portfolio companies are regulated by overseas laws, thus providing them with the opportunity to avoid legal restrictions in China, such as the prohibition on the use of convertible security and preferred stock. Meanwhile, for a long time, some of the most widely used mechanisms in venture capital investment were not made available to DVCFs. Although restrictions have been gradually relaxed since 2004 when the Company Law was amended, numerous problems remain.

\section{Data}

\subsection{Data and Sample}

The data used in our study are mainly obtained from China's Manufacturing Firm Survey Database (1998-2007), which is published annually by the National Bureau of Statistics of China since 1998. This database consists of virtually all manufacturing firms in China, including all SOEs, individually owned firms, joint ventures, and foreign firms, with annual sales of at least 5 million RMB. These firms produce over $90 \%$ of China's gross industrial output. ${ }^{9}$ The dataset covers major financial information, age, location, the number of employees, and ownership structure of the firms for all the survey years. R\&D investment information, however, is only available for 2005, 2006, and 2007.

The investment information for VC-backed firms comes from VentureXpert. For each VC-backed firm, the dataset includes the name, location, industry (in four digits) of the firm; the

\footnotetext{
${ }^{9}$ The database is also used by numerous firm-level analyses, including those by Chuang and Hsu (2004) and Hsieh and Klenow (2009).
} 
total amount of venture investment gained by the company; the number of VCs involved in each deal; and the number of venture financing rounds for each firm. For each VC, the dataset provides information on its age, location, and the amount of funds under management, among others.

Initially, we extract a list of 2,527 VC-backed firms receiving their first venture capital investment prior to January 2011 from the VentureXpert database. Their names are in English. We confirm their Chinese names through websites and other online sources, and obtain the Chinese names of 2,518 firms. We then match the list of Chinese names with China's Manufacturing Firm Survey Database (2007). After matching, we identify 536 VC-backed firms covered by China's Manufacturing Firm Survey Database (2007). The sharp decrease in the number of firms reflects the presence of numerous VC-backed firms in the Internet service or software-related industries, which are not covered by the survey database. Moreover, a large number of firms that received their first round of venture capital investments after 2007 are recorded. We screen out firms that received their first round of venture capital investments prior to 2000 and after 2006. This screening strategy enables us to capture the performance and R\&D activities of firms before and after the venture capital investment. Given that our panel dataset is between 1998 and 2007, we cut two years at both ends to estimate pre- and post-investment effects. We are then left with 258 VC-backed firms in the 2007 survey data. This sample represents approximately $50 \%$ of all manufacturing firms in China that received venture investment between 1998 and 2011.

To compare VC-backed and non-VC-backed firms in terms of performance and R\&D activities, we construct a control group for comparison purposes. We build the control group in several steps to ensure that our results are not driven by a specific matching method. First, we select all non-VC-backed firms from China's Manufacturing Firm Survey Database. We then match the VC-backed firms with non-VC-backed firms by industry (at the three-digit SIC level) and location (at the provincial level). Finally, we employ the methodology of randomly drawing one-to-five matched pairs to build the control group. To ensure that our control group is representative, we repeat this random draw methodology 15 times, and the results are consistent.

Table 1 shows the industry distribution of the sampled VC-backed firms at the two-digit SIC level. As shown in the table, VC-backed firms are concentrated in high-tech industries, 
including telecommunication and computer products, electronic and electrical equipment, chemical products, pharmaceutical products, machinery and equipment products, and instrumentrelated products. Firms in these industries comprise $60 \%$ of the total sampled VC-backed firms. This figure is consistent with the industry distribution of VC-backed firms reported by Zero2IPO (2001-2009). The distribution of the sampled VC-backed firms suggests that our samples fairly represent the entire sample of VC-backed firms.

\subsection{Variables}

The performance and R\&D activities of firms are our major interests in this study. We estimate the performance and $R \& D$ activities in different dimensions, namely, profitability, labor productivity, sales growth, and R\&D investment. Profitability is measured by return on sales $(R O S)$ and return on equity $(R O E)$ of the firm. Labor Productivity is measured by net profit per employee of the firm. Sales Growth is the annual sales growth of the firm. We use R\&D Ratio to measure the $R \& D$ activities of a firm. This variable is $R \& D$ expenditure over total sales of the firm.

We are interested in the changes in performance and $R \& D$ activities of entrepreneurial firms in relation to venture capital investment within the examination period. Hence, we need a variable to distinguish whether the firm is backed by VCs. The VC Dummy variable is equal to 1 if the firm is backed by VCs, and equal to 0 if otherwise. A significantly positive coefficient on this variable implies that VC-backed firms generally have higher efficiency. Second, the $V C$ Entry dummy variable is used to divide the entire examination period into two parts, namely, the period before and after venture investment. $V C$ Entry is equal to 0 for the period before the investment is made, and is equal to 1 for the period after the investment is made. The value of this variable for the firms in the control group is determined by its pair in the VC-backed group. We use this variable to test the structural change effect before and after the infusion of venture capital investment. Finally, we include an interaction term of VC Dummy and VC Entry in our regression to test whether the performance increase after VC entry is the same for VC-backed and non-VC-backed firms. The interaction term VC Post is equal to 1 if the observation is for a VC-backed firm in the period after the investment is made, and equal to 0 if otherwise. 
We are also interested in how the different types of VCs add value to their portfolio firms. As previously mentioned, domestic and foreign VCFs differ in several aspects mainly due to the regulatory restrictions in China. To gain more insight into the relationship between VC incentives and their contributions to entrepreneurship, we compare the performance and R\&D activities of firms backed by these two groups of VCFs. VCFs typically syndicate investment, and the lead VCF is intensively involved in the governance of portfolio companies. We use the headquarters location of the lead VCF to determine whether firms are backed by FVCFs or DVCFs. Following the literature (Lee and Wahal, 2004; Nahata, 2008), we define the lead venture capital investor as that making the largest total investment across all rounds of funding in an entrepreneurial firm. $F V C$ is a dummy variable that equals to 1 if the headquarters of the lead VCF is located outside China, and equals to 0 if otherwise. $D V C$ is a dummy variable that equals to 1 if the headquarters of the lead VCF is located within China, and equals to 0 if otherwise. DVC Post is the interaction terms of VC Entry and DVC Dummy and FVC Post is the interaction term of VC Entry and FVC Dummy.

Finally, we are interested in whether syndicated investment may increase the quality of the monitoring effects of VCs. Syndication is a dummy variable that equals to 1 if the firm is backed by more than one VC, and equals to 0 if otherwise. Non-Syndication is a dummy variable that equals to 1 if the firm is backed by a single VC, and equals to 0 if otherwise. Syn-Post and Non-Syn-Post are the interaction terms of VC Entry and Syndication and Non-Syndication, respectively.

Five control variables are included in the analysis, namely, age, size, leverage ratio, percentage of state shares, and employee treatment of the firm. China's Manufacturing Firm Survey Database provides information on the founding date of the firm. We use this information to calculate Firm Age. Firm size is measured by the total number of employees of the firm. We also include leverage ratio in the estimates. Leverage is the total liability divided by the total assets of a firm. Venture capital investment does not require collateral. However, investing in entrepreneurial firms is associated with serious information and uncertainty issues. Hence, VCs may consider the liquidation value of firms when making investment decisions, inducing them to select firms with low leverage ratios. Additionally, we control for the ownership structure of the firm. State Ownership is the ratio of state-owned stake divided by the total equity of a firm. 
Being heavily involved in the governance of their portfolio companies, VCs are concerned with the ownership structure of firms. Major institutional shareholders would affect the extent to which VCs may influence decision making in their portfolio companies. VCs may prefer firms with less state shares because the non-profit-oriented interests of state owners may conflict with their interests. Additionally, state ownership may affect VC governance after the investment is made. Lastly, we include Employee Treatment, measured by the average wage of employees of the firm, in the panel analysis. Employee treatment is associated with firm performance and R\&D activities as an inducing or outcome factor (Titman, 1984; Pfeffer, 1996). We therefore control for this effect when we examine the post-investment performance and R\&D investment dynamics of firms.

\subsection{Summary Statistics}

Table 2 provides the summary statistics of VC-backed firms, including means, minimums, maximums, and standard deviations of operational, financial, and corporate governance statistics, for the VC-backed firms. The average value of ROS is roughly 0.1 , whereas the average value of $\mathrm{ROE}$ is approximately 0.23 in the $\mathrm{VC}$ investment year. The average growth rate of the VCbacked firms is 0.31. Labor productivity of the VC-backed firms is roughly 74.79. At the same time, on average, VC-backed firms invest $1 \%$ of their total sales in R\&D activities.

Table 3 reports the t-test results on the differences in profitability, sales growth, productivity, and R\&D input between VC-backed and non-VC-backed firms. We compare the two groups of firms from the onset of VC investment to two years later. First, in the year of VC entry, VC-backed firms have statistically better profitability than non-VC-backed firms. VCbacked firms have twice as much ROS and about 1.22 times as much ROE as non-VC-backed firms. Second, VC-backed firms have higher labor productivity. The net profit per employee of VC-backed firms is about 2.3 times larger than that of non-VC-backed firms. Third, VC-backed firms enjoy 2.8 times higher sales growth than that of non-VC-backed firms at the time of the investment. Fourth, VC-backed firms invest three times more in R\&D activities than non-VCbacked ones at the time of VC entry. More importantly, all the observed differences in ROS, $\mathrm{ROE}$, labor productivity, and R\&D ratio persist for at least two years after VC entry, and these 
differences increase with time. However, the sales growth of the firms seems to be more fluctuated over the years.

To ensure that our results are not affected by outliers, we apply the Wilcoxon test on the median. We use the two-tailed Wilcoxon rank-sum test to determine whether or not the performance difference between VC-backed and non-VC-backed firms from the onset of venture investment stay after two year of the investment (Kazmier and Pohl, 1984). Table 3 indicates that our results are robust to outliers.

\section{Findings on the contribution of VCs to entrepreneurial firms}

\subsection{Do VC-backed firms outperform non-VC-backed firms?}

Our first question is whether VC-backed firms outperform non-VC-backed firms. Table 4 shows the regressions that compare the ROS, ROE, labor productivity, sales growth, and R\&D investment of VC-backed and non-VC-backed firms. As shown in Models 1 and 2, VC Dummy is significantly positive, implying that VC-backed firms outperform their non-VC-backed counterparts in terms of profitability. On average, the ROS and ROE of VC-backed firms are higher than that of non-VC-backed firms by 0.03 and 0.05 , respectively, which is roughly $30 \%$ of the average value of ROS and $20 \%$ of the average value of ROE of VC-backed firms at the time of the investment. Model 3 demonstrates the regression results on sales growth. On average, the sales growth of VC-backed firms is higher than that of non-VC-backed firms by 0.2 , which is over $60 \%$ of the average growth rate of VC-backed firms at the time of the venture investment. Model 4 reports the labor productivity of the firms. The results are similar to those we find on profitability. VC-backed firms generally have higher labor productivity than non-VC-backed ones. On average, the net profit over the number of employees of VC-backed firms is higher than that of non-VC-backed firms by 28.29 , which is roughly $38 \%$ of the average labor productivity of VC-backed firms at the time of the venture investment. Model 5 shows the R\&D expenditure over total sales. VC Dummy is significantly and positively correlated with R\&D expenditure, which suggests that VC-backed firms invest more in R\&D activities compared to their non-VCbacked counterparts. On average, VC-backed firms invest approximately $0.8 \%$ more of their total sales in R\&D activities. To ensure the reliability of our results, we repeat the above estimates using the other 14 control groups matched by industry and location of the firms. The 
findings remain robust. ${ }^{10}$ To summarize, similar to the findings in developed economies, VCbacked firms in China outperform non-VC-backed firms in terms of profitability, labor productivity, and sales growth. The same outcome is observed in the case of R\&D investment. VC-backed firms invest more in R\&D activities than non-VC-backed firms do.

\subsection{Do VCs select better performing firms?}

We conduct logit regressions, a set of cross-sectional data analyses on the firm's performance and $\mathrm{R} \& \mathrm{D}$ activities in the year before the $\mathrm{VC}$ investment is made, to determine whether VCs choose to invest in better performing firms. The dependent variable is VC Dummy.

Table 5 presents the logit regression results. In Models 1 to 5, we separately put the performance variables into the estimates. The ROE, ROS, labor productivity, sales growth, and R\&D investment of the firms are all significantly and positively correlated with VC Dummy. The results suggest that firms are more likely to be backed by VCs if they have higher profitability, growth rate, and labor productivity. Additionally, firms investing more in R\&D activities seem to have a higher probability to gain venture investment. In Model 6, we put all the performance variables together into the regression estimate. Specifically, an increase in the ROS of the firm by 0.1 from its mean (about $100 \%$ of its mean) increases its probability of being selected by VCs by $4 \%$, and an increase in the ROE of the firm by 0.2 from its mean (about $100 \%$ of its mean) increases its probability of being selected by VCs by $2 \%$. Similarly, an increase in the net profit per employee of the firm by 75 from its mean (100\% of its mean) increases its probability of being backed by VCs by $7.5 \%$. Model 7 reports the relationship between R\&D investment and the chance of being backed by VCs. Data on R\&D expenditure are available only after 2005; thus, the number of observations decreases from 929 to 709 when we incorporate R\&D into our regression analysis. $\mathrm{R} \& \mathrm{D}$ ratio is shown to be significantly and positively correlated with $V C$ Dummy, which suggests that firms investing more in $\mathrm{R} \& \mathrm{D}$ activities may be more attractive to VCs. An increase in the R\&D investment of the firm by 0.01 from its mean (100\% of its mean) increases its probability of being selected by VCs by $2.6 \%$.

\footnotetext{
${ }^{10} \mathrm{We}$ also repeat our regressions using the entire sample of non-VC-backed firms. The results also remain robust. However, when we use the full sample, the total number of observations is $2,713,690$, and $99.9 \%$ of the observations are for non-VC-backed firms. The estimated coefficient for VC Dummy may be biased, given the little variation in this variable.
} 
We also control for the leverage ratio, size, age, and state share of the firm. Firm age is observed to be significantly and negatively correlated with VC Dummy. This result implies that everything being equal, VCs tend to choose younger firms in China similar to what they do in developed countries. Moreover, VCs seem to have a preference for investing in larger firms. However, no evidence confirms the relationship between the state share of the firm and the investment decisions of VCs. An interesting finding is that in most cases, the leverage ratio is significantly and positively correlated with VC Dummy. This finding appears counterintuitive, but it may exactly reflect the value of venture capital investment. VCs may see some missing variables in financial statements, such as an innovative technology, a completely new and promising business model, and an underdeveloped but promising market. Often, entrepreneurs with new ideas are financially constrained. They have to borrow from families or friends at the startup stage of their businesses, and reaching the break-even stage could take a few years. From the traditional viewpoint, these businesses may be over leveraged. However, given their expertise, VCs may see the intangible value of certain projects that compensate for the so-called "downside risks" of investing in entrepreneurial firms.

Although the logit regressions show that firm performance and R\&D investment are strongly and positively correlated with the probability of firms being backed by VCs, we may not conclude that the findings are caused by the ex-ante project selection efforts of VCs because some other unobservable factors may have contributed to the results. One alternative explanation for the findings is that VCs attract rather than select firms with higher profitability, labor productivity, and R\&D investment. Entrepreneurs may minimize the uncertainty of being rejected by VCs by approaching VCs only when their firms are already in a good situation to seek VC investment. Furthermore, entrepreneurs who approach VCs may only be those who can achieve better financial performance and have the vision and knowledge of the potential added value of $\mathrm{VC}$ investment. We cannot rule out these alternative explanations because we have information neither on which entrepreneurs seek venture capital investment nor on which projects are rejected by VCs. Nonetheless, we attempt to address this concern through interviews with VCs.

We conducted interviews with 37 VCs in China between 2005 and 2006. The interview data are presented in Appendix 1. The interviews show that the ex-ante project assessment 
process is very selective, resulting in a very high rejection rate. According to the interviews, only 1.3 of 100 business plans submitted to VCs receive investment in China. Over 85\% of the interviewed VCs suggest that assessing projects before making investment decisions takes more than three months. VCs also devote much effort to ex-ante project selection. All VCs visit entrepreneurial firms for more than six times before making any investment decision. During the due diligence process, VCs assess projects in various ways, such as visiting customers and suppliers of firms, tracking the business and personal records of entrepreneurs and management teams, consulting experts in relevant markets, assessing technology improvements, and consulting accounting and auditing firms. Moreover, all the interviewed VCs emphasize that they carefully go through project financial statements when evaluating projects.

The interviews also reveal that VCs consider the financial performance and technological improvements of entrepreneurial projects as important aspects when making investment decisions. As shown in Table A-2, 18 out of the 38 criteria are related to the product, market, and financial aspects of entrepreneurial firms. We also ask VCs to list 10 essential criteria without which they will definitely reject projects regardless of other aspects. As shown in Table A-3, half of the 10 essential criteria are related to the market, product, and financial outlook of projects. ROS, labor productivity, and R\&D investment are factors that reflect not only the financial situation of firms, but also their market penetration situation and strategies for technological improvements. Furthermore, these factors indirectly reflect the capability of entrepreneurs and management teams. Although several important factors, such as the personality of entrepreneurs and the features of management teams, are excluded from our regression analysis, our estimates cover important elements affecting ex-ante project selection by VCs.

The interviews suggest that VCs exert much effort in ex-ante project selection, and the selection criteria are consistent with the aspects we find in our regression analysis. However, we do not seek to claim that the ex-ante project selection process is the sole explanation for the results of our statistical examinations. Rather, we suggest that these supportive findings from the interviews help us to identify the mechanisms underlying our regression estimates.

In sum, companies with better financial performance and higher sales growth and labor productivity have a higher probability of being funded by VCs in China. In addition, companies 
investing more in R\&D activities have more chances to be financed by VCs. These findings are consistent with studies conducted in the context of developed economies (MacMillan et al., 1985; Kortum and Lerner, 2000; Chemmanur et al., 2011). Our results also suggest that traditional finance theories do not always apply to venture capital investment. For instance, no evidence shows that leverage ratio, which is typically considered by banks when making investment decisions, has negative effects on being selected by VCs.

\subsection{Do VCs add value?}

\subsubsection{Propensity score matching}

The results from the previous subsections confirm that VC-backed firms outperform nonVC-backed firms, and part of the outperformance comes from VC selection efforts. In this subsection, we examine whether the post-investment monitoring and support efforts of VCs add value to their portfolio companies. Specifically, we focus on the difference-in-difference estimates of performance and R\&D investment of the VC-backed and non-VC-backed firms.

As shown in Section 4.2, VCs select firms that perform better and invest more in R\&D activities. To capture the difference-in-difference effects, we need to initially control for the selection biases. We construct a new control group of non-VC-backed firms using the PSM methodology, in which we match firms with different dimensions (Rosenbaum and Rubin, 1983; Chemmanur et al., 2011). We particularly require the matched firm to be in the same industry (at the three-digit level), the same location, and have a similar level of profitability measured by $\mathrm{ROE}$ in the year before the firm is backed by $\mathrm{VC}$ investment. We use one to five pairs for matching. Both t-test (t-statistics $=0.102)$ and two-tailed Wilcoxon rank-sum test (z-statistics = 0.662) show that after the matching, no statistically significant difference in profitability is observed between the two groups of firms.

Based on this control group matched by propensity scores, we estimate the value-added effects of venture investment. To capture the evolution of firm operations and identify whether firms show improved performance and $R \& D$ activities after the venture capital investment is made, we add VC Dummy, VC Entry, and VC Post to the estimates. VC Post, the interaction term

of the treatment effects of venture investment (VC Dummy) and before and after effects ( $V C$ 
Entry), is our major interest as we aim to the estimate the difference-in-difference effects of venture investment on performance and $R \& D$ activities of the firm. A significantly positive coefficient of VC Post indicates that the increase in pre- and post-investment performance is larger for VC-backed firms than for non-VC-backed firms.

Table 6 reports the results of the estimates on the performance and R\&D investment of VC-backed and non-VC-backed firms matched by the PCM approach. Models 1 and 2 report the regression results on profitability measured by $R O S$ and $R O E$, respectively. Both $R O S$ and $R O E$ are significantly and positively correlated with VC Post, indicating that the treatment effect of venture investment on the profitability of the firm is magnified after the investment is made. The treatment effect is increased by 0.023 for $R O S$ and 0.079 for $R O E$ after the investment is made, which is roughly $23 \%$ of the average of the ROS and $35 \%$ of the ROE of the VC-backed firm at the time of investment, respectively. We also examine the sales growth of the firms, and Model 3 reports the regression results. VC Post is observed to have no statistically significant relationship with the sales growth of the firm, although VC Dummy is significantly and positively correlated with the sales growth. The result suggests that VC-backed firms enjoy higher growth rate in sales compared to their non-VC-backed counterparts. However, no evidence shows that VC-backed firms enjoy further improved sales growth compared to their non-VC-backed counterparts after the investment is made.

Model 4 demonstrates the regression for labor productivity of the firm. Similar to the results on profitability, we find a significant and positive relationship between VC Post and the labor productivity of the firm. On average, compared to non-VC-backed firms, VC-backed firms enjoy further increase in labor productivity by 17.17 after the investment is made, which is roughly $23 \%$ of the average labor productivity of the VC-backed firms at the time of the investment. These findings suggest that the gap in profitability and labor productivity between VC-backed and non-VC-backed firms is further widened after the venture capital investment is made.

Finally, Model 5 reports the R\&D expenditure over total sales of the firm. VC Dummy is observed to be statistically and positively correlated with the R\&D investment of the firm, although no statistically significant relationship is found between R\&D investment and VC Post. 
The result suggests that VC-backed firms invest more in R\&D activities compared to their nonVC-backed counterparts. However, VC involvements do not seem to further magnify the gap in R\&D investment between VC-backed and non-VC-backed firms.

In sum, the above estimates suggest that VC-backed firms outperform non-VC-backed firms in terms of profitability, labor productivity, sales growth, and R\&D investment. However, the value-added effect is mainly observed in profitability and labor productivity; that is, the difference between VC-backed and non-VC-backed firms is significantly magnified after the venture capital investment is made. No evidence demonstrates that VCs add significant value in terms of sales growth or R\&D investment of the firm. Overall, our results are similar to Chemmanur et al. (2011), who report that the TFP of the VC-backed firms is significantly improved compared to non-VC-backed firms in the United States after controlling the selection factors. However, our results differ from the findings of Puri and Zarutskie (2012), which suggest that the sales growth of VC-backed firms is higher than that of non-VC-backed firms, whereas the profitability of VC-backed firms is lower than that of non-VC-backed firms.

\subsubsection{Identification issues on the value-added effects of VCs}

The estimates in the previous subsection not only show a strong and positive relationship between venture investment and firm performance and R\&D investment, but also suggest that the extent of the positive effect of venture capital investment is further increased for profitability and labor productivity after the investment is made. Although the PSM methodology helps us to control the selection issues, it has certain limitations; that is, it is incapable of capturing the effects of unobservable variables. Several missing variables, not VC involvement, may contribute to improved performance after the venture capital investment is made. For instance, VCs choose to invest in better performing companies ex ante. These better performing companies selected by VCs may have better chances of seizing several external opportunities compared to non-VC-backed firms; thus, they grow at an improved pace after the venture capital investment is made. In this case, the value-added effects of venture investment we find in Table 6 may be inflated.

To address the above identification concern with unobservable variables, we employ the two-staged Heckman estimation procedure for identifying the value-added effects of venture 
investment. We particularly employ two instrumental variables to separately predict the probability of the firm being backed by venture investment in the first stage estimation. The first instrumental variable is IPO_CN, which refers to the number of IPOs in the Chinese stock markets from the city where the firm is located one year before the investment is made. The second instrumental variable is IPO_All, which refers to the total number of IPOs in the Chinese and overseas stock markets ${ }^{11}$ from the city where the firm is located one year before the investment is made.

We choose these two instrumental variables because they are correlated with the demand and supply of venture capital investment in the city, but are independent of the performance of VC-backed firms. The institutions in China determine the number of IPO cases across regions. The probability of a firm going IPO may predict whether a firm may be selected by VCs. IPO is evidently the most successful exit approach for venture capital investment. The IPO of portfolio firms provides VCs with the highest financial returns compared to other divestment approaches, and brings good reputation to VCs (Brav and Gompers, 1997; Chemmanur et al., 2011). Thus, the higher the chance of the firm to be listed soon, the more attractive the firm becomes to VCs.

However, the equity share issuance of firms has been heavily governed and influenced by the central government in China. Under a quota system, the central government determines the total number of shares to be issued in the country, and then allocates stock issuance quotas to regions and ministries. Regional governments, in turn, allocate quotas to selected companies for going public through IPOs. Studies indicate that even after 2003 when the quota system was abandoned, the issuance of public offering continued to be tightly controlled by the central government (i.e., CSEC); thus, the number of annual IPO cases indicated the ease of obtaining IPO approval from the government for the following year ( $\mathrm{Du}$ and $\mathrm{Xu}, 2009$ ). A number of VCbacked firms, in particular, foreign VC-backed firms, choose to be listed on foreign stock exchange markets. Nonetheless, even for the issuance of public offerings in overseas stock exchange markets, a firm needs to gain approval from the Ministry of Foreign Trade and Commerce (MFTC) prior to 2005 and register with MFTC after 2005. That is, firms still need to undergo complicated approval procedures for IPO listing in overseas stock markets. The number

\footnotetext{
${ }^{11}$ Most of the Chinese firms choose to be listed on the Hong Kong and U.S. stock markets; thus, we use the number of firms going IPO in these two markets to indicate the number of IPO cases of Chinese firms in overseas markets.
} 
of IPO cases in the previous year has a significant implication on the IPO cases for the subsequent year. Moreover, the major returns of venture capital investment come from the VCbacked firms that are listed in the stock markets. Nevertheless, we suggest that VCs prefer to invest in companies located in areas that have more quotas or have better chances to list more firms in the stock markets. However, the number of IPO cases is not directly correlated with the performance of individual firms. Hence, we suggest IPO_CN and IPO_All serve as good instrumental variables.

Table 7 shows the two-staged least square estimations. Panel A shows the first stage estimations, in which we regress VC Dummy on the set of independent variables, including our instrumental variables. The first stage regressions presented in Panel A confirm that $I P O \_C N$ and $I P O \_A l l$ are statistically qualified instrumental variables as they are both significantly and positively correlated with VC Dummy for all the estimates.

Panel B of Table 7 shows the results of the second stage regressions. Models 1 to 5 of Panel B report the second stage regressions, in which VC Dummy is instrumented by IPO_CN. The instrumented VC Dummy is significantly and positively correlated with all the performance measurements and R\&D investment of the firm. Moreover, VC Post is significantly and positively correlated with ROS, ROE, and labor productivity. These results are consistent with the results shown in Table 6, which suggest that the differences of the firms in terms of profitability and productivity are magnified after the venture capital investment is made. However, different from the results in Table 6, we find a statistically significant and positive relationship between VC Post and R\&D investment of the firm after VC Dummy is instrumented by IPO_CN. Models 6 to 10 of Panel B report the second stage regressions, in which VC Dummy is instrumented by IPO_All. The results are consistent with the findings shown in Models 1 to 5. The only difference is that the relationship between VC Post and ROS becomes statistically insignificant.

In sum, using the two-staged Heckman estimation enables us to identify the probability of a firm being selected by venture capital investment. The results of the two-staged least square regressions confirm the value-added effects of VCs on the profitability and labor productivity of firms. 


\section{Do different types of VCs add different values?}

In this section, we determine whether different types of VCs vary in their effects on the performance and R\&D activities of the firms they invest in. As previously mentioned, the foundation of the value-added effect argument is that VCs exert effort to monitor and support their portfolio companies after the capital investment is made. This argument suggests two major requirements that enable VCs to add value to their entrepreneurial companies, namely, expertise to provide helpful suggestions and efficiently monitor operations, and motivation to exert effort and utilize expertise. Both requirements are indispensable. Logic implies that if VCs add value to their portfolio companies, companies backed by VCs with more expertise and high-powered incentives should outperform those backed by VCs with less expertise and low-powered incentives. Chemmanur et al. (2011) assert that in the United States, firms backed by VCs with higher reputation perform better than the others.

The institutional setting in China provides a perfect opportunity for us to test the above assumption. As mentioned in Section 2, VCFs in China are divided into two distinct groups due to regulatory restrictions. Exogenous factors, including restrictions on limited partnerships, foreign institutional investors, and capital control, have resulted in various differences between these two groups of VCFs. We interview 37 VCs from 34 venture capital firms; 19 out of 22 FVCFs are structured as limited partnerships, whereas the domestic ones are structured as limited companies. FVCFs are decentralized in decision making, and they provide high-powered "payfor-performance" compensation to individuals. In contrast, DVCFs are centralized in decision making, and compensation is not directly and closely related to individual performance. In short, FVCFs provide high-powered incentives to VCs, whereas DVCFs provide low-powered incentives to VCs.

Foreign VCs are also much more experienced than domestic VCs. Venture capital remains a new concept in China, a country that generally lacks experts in private equity investment. According to our interviews with VCs in 2005 and 2006, foreign firms have longer experience in the venture capital industry than domestic ones. The average age of FVCFs (DVCFs) in 2006 is 11.5 (6.33) years. Moreover, given restrictions in governance and incentive

schemes, DVCFs can hardly attract venture capital experts from overseas markets. According to our interviews, domestic VCs are former government officers or managers of large corporations. 
In contrast, most foreign VCs have investment banking or entrepreneurial experience that is closely related to private equity financing. Learning curve theory suggests that more experience and accumulated knowledge reduce costs and improve efficiency (Spence, 1981; Ghemawat and Spence, 1985). We therefore suggest that foreign VCs have more expertise in monitoring and providing support to their portfolio companies compared to domestic VCs.

Table 8 reports the performance and R\&D activities of firms separately backed by FVCFs and DVCFs. Models 1 and 2 show that DVC Dummy and FVC Dummy are significantly and positively correlated with ROS and ROE. The coefficients of DVC Dummy are also higher than those of FVC Dummy. However, no statistically significant relationship is observed between DVC Post (the interaction term of China VC and VC Entry) and ROS or ROE. Conversely, we find a significant and positive relationship between FVC Post and ROS and ROE. These results suggest that DVC-backed firms outperform non-VC-backed firms. However, the outperformance of the DVC-backed firms seems to be mainly explained by the ex-ante selection efforts of DVCs, but not their ex-post value-added efforts. As a comparison, the outperformance of the FVCbacked firms seems to come from both the ex-ante selection and the ex-post value-added efforts.

Model 3 of Table 8 reports the regression for the sales growth of the firm. DVC Dummy and FVC Dummy are significantly and positively correlated with the sales growth of the firm. However, no statistically significant relationship is observed between FVC Post and sales growth. Furthermore, DVC Post is even significantly and negatively correlated with sales growth. The results suggest that although both DVC-backed and FVC-backed firms enjoy higher sales growth rate, the effects are mainly contributed by the ex-ante selection efforts of VCs.

We examine the labor productivity of the firms in Model 4 of Table 8. DVC-backed and FVC-backed firms enjoy significantly higher labor productivity than non-VC-backed firms. Moreover, after receiving the venture investment, DVC-backed and FVC-backed firms enjoy a magnified improvement in labor productivity compared to non-VC-backed firms. The results suggest that both DVCs and FVCs select firms with higher labor productivity to invest in. At the same time, both types of VCs help their portfolio firms to further improve the labor productivity after the investments are made. 
Lastly, we explore the R\&D investment of the firms backed by different VCs. As Model 5 of Table 8 shows, DVC Dummy and FVC Dummy are significantly and positively correlated with the R\&D expenditure over total sales of the firm. However, no statistically significant relationship is observed between DVC Post and R\&D investment. We find a significant and positive relationship between FVC Post and R\&D investment. These results indicate that DVCs typically choose firms that invest more in R\&D activities, while they do not seem to push the firms to further intensify their R\&D efforts after the investment is made. Conversely, FVCbacked firms not only invest more in $R \& D$ activities, but also significantly intensify $R \& D$ investment after the investment is made compared to the firms in the control group.

The above examinations support our assumptions on the relationship between the experience and incentives of VCs and the performance of their portfolio companies. Primarily, both DVC-backed and FVC-backed firms outperform non-VC-backed firms in terms of profitability, labor productivity, sales growth, and R\&D investment. However, the effect for DVC-backed firms mainly comes from ex-ante project selection. In other words, domestic VCs mainly select companies with higher profitability, higher labor productivity, higher sales growth, and a higher degree of R\&D intensity, while they do not seem to add value after the investment is made, with labor productivity as the only exception. Compared to DVCs in China, FVCs have more experienced investment experts and provide high-powered incentives to investment professionals, thus adding more value to their portfolio companies after the investment is made. This result is consistent with the findings of Chemmanur et al. (2011) that VCs may be heterogeneous in their capability to add value to their portfolio companies after the investment is made.

\section{Does syndicated investment add more value to firms?}

In this section, we examine the impact of the investment approach on the value-added effects of VCs on the performance and R\&D activities of firms, with the focus on syndicated investment. Syndication is one of the most potent investment approaches in venture investment. ${ }^{12}$ Theoretical studies suggest that venture capitalists may share information and expertise to gain more access to potential deals, improve ex-ante decision making, provide more value-added

\footnotetext{
${ }^{12}$ According to Sorenson and Stuart's (2001) survey of the U.S. venture capital market, over two-thirds of 7,590 venture capital-backed firms in their data are financed by more than one venture capital firm.
} 
assistance to entrepreneurs, and increase capability in monitoring portfolios by syndicating (Casamatta and Haritchabalet, 2007; Cestone et al., 2006). Another argument is that syndication of venture investment is mainly for window dressing purposes; that is, syndication is a mechanism through which VCs collude to overstate their past performance to potential investors. Empirical studies support the arguments by demonstrating that syndicated deals have higher returns (Brander et al., 2002) and are more likely to have an exit approach and achieve higher IPO valuations (Chemmanur and Tian, 2009; Tian, 2011). All the existing empirical studies focus on the effects of syndication on $\mathrm{VC}$ returns, which are typically measured by the exit rate, exit channel, and exit value. However, to our knowledge, how syndication affects the performance and $R \& D$ activities of entrepreneurial firms based on firm-level data has not been estimated so far. Thus, we extend the extant studies by examining the value-added effects of syndicated investment.

To capture the syndication effects on the performance and R\&D investment of the firm, we include Syndication and Non Syndication into the regressions to distinguish syndicated VCbacked firms, non-syndicated VC-backed firms and non-VC-backed firms. We also include $V C$ Entry and the interaction terms of VC Entry with Syndication and Non Syndication respectively to estimate the dynamics of the syndication effects.

Table 9 reports the results on the effects of syndication. Syndication and Non-Syndication are significantly and positively correlated with the ROS, labor productivity, sales growth, and R\&D expenditure over total sales of the firm. This finding suggests that whether or not the investment is syndicated, VC-backed firms have higher ROS, labor productivity, sales growth, and R\&D investment compared to non-VC-backed firms. We then examine the value-added effects of the two different types of investment by adding Syndication Post and Non-Syndication Post, the interaction terms between VC Entry and Syndication and Non-Syndication respectively, to the estimates. Syndication Post is found to be statistically and significantly correlated with all the performance and R\&D variables, except sales growth. However, no statistically significant relationship is observed between any performance or R\&D variables and Non-Syndication Post. The results imply that the ex-ante screening efforts rather than the ex-post value-added efforts of VCs contribute more to the outperformance of the firms backed by non-syndicated investment. Firms backed by syndicated investment, however, experience magnified improvements in financial performance, labor productivity, and R\&D investment compared to their non-VC- 
backed counterparts. The empirical findings confirm the theoretical arguments that syndication may better facilitate VCs to monitor and provide more value-added assistance to entrepreneurial firms.

\section{Conclusion}

This paper examines the contribution of venture capital investment to the performance and $R \& D$ activities of entrepreneurial firms in China. Based on the results of firm-level panel data analysis, we find that VCs contribute to entrepreneurial firms in China in two ways. First, VCs in China select firms that have better financial performance and higher investment in R\&D activities. Second, VC-backed firms experience magnified improvement in performance after the venture capital investment is made. We use the PSM methodology to distinguish the effects of the ex-ante screening and ex-post monitoring/support efforts of VCs. At the same time, we use the two-staged Heckman estimation to address identification issues; the results remain robust. These findings suggest that VCs operating in China function similarly to those in developed economies; that is, they not only choose to fund better performing firms, but also add value to these firms after the investment is made. Furthermore, we find that the value-added effects of VCs are heterogeneous depending on the different types of VCs and varied investment approaches. FVCs not only select better performing firms to invest in, but also add significant value to these firms after the investment is made in China. However, no evidence demonstrates that firms backed by DVCs experience significant performance improvements after the investment is made. Lastly, firms backed by syndicated investment gain significantly magnified performance improvement compared to their non-VC-backed counterparts, whereas firms backed by non-syndicated investment do not.

This study contributes to the literature on venture capital investment in three aspects. First, following Chemmanur et al. (2011), the current study is among the first attempts to answer a puzzling question earlier raised by Kortum and Lerner (2000): "If VC-backed firms outperform non-VC-backed firms, does the advantage come from ex-ante project selection or from monitoring and control after investment is made?" Second, we extend the existing studies (Chemmanur et al., 2011; Kaplan et al., 2009) by further exploring the factors affecting the value-added effects of VCs on entrepreneurial firms, with the focus on the experience and 
incentives of the VCs and the approach of the investment. Lastly, this study is the first systematic estimation on the contribution of VCs to entrepreneurial firms in China, where the financial and legal systems are distinctly different from those in Western countries (Allen et al., 2005). Hence, we contribute to the literature on corporate finance and R\&D activities in emerging markets by examining the impact of institutions (Hu et al., 2005; Jefferson et al., 2006; Cull et al., 2009).

The current study raises several questions for further research. First, are the value-added effects of venture investment mainly caused by the monitoring efforts or support activities of VCs? Second, if venture capital investment enhances the financial performance and R\&D investment of firms, does it also enhance innovation (i.e., R\&D outputs)? Third, why and how does venture capital investment help entrepreneurial firms under the remarkably weak institutions in China? Fourth, what are the key factors that result in the distinctive effects of DVCs and FVCs on entrepreneurial firms? Finally, through which mechanisms do the different investment approaches affect the performance of entrepreneurial firms?

\section{Acknowledgments}

The authors thank seminar participants at The University of Hong Kong, Seoul National University, and Peking University for their generous comments. Both authors acknowledge the financial support from the seed research funds provided by the University of Hong Kong, and the Theme-based Research Scheme Project on "Enhancing Hong Kong's Future as a Leading International Financial Centre" (T31-717 112-R) provided by RGC, HK SAR. The authors assume responsibility for any error.

\section{References}

Allen, F., Qian, J., and Qian M., 2005. Law, Finance, and Economic Growth in China, Journal of Financial Economics, Vol. 77, No. 1, pp. 57-116.

Barry, C., Muscarella, C., Peavy III, J., and Vetsuypens, M., 1990. The Role of Venture Capital in the Creation of Public Companies: Evidence from the Going-public Process. Journal of Financial Economics, Vol. 27, No.2, pp.447-471. 
Bradley, D. and Jordan, B., 2002. Partial Adjustment to Public Information and IPO Underpricing. Journal of Financial and Quantitative Analysis, Vol. 37, No.4, pp. 595-616.

Brander, J.A., Amit, R., and Antweiler, W., 2002. Venture Capital Syndication: Improved Venture Selection vs. the Value-Added Hypothesis. Journal of Economics \& Management Strategy, Vol. 11, No. 3, pp. 423-452.

Brav, A. and Gompers, P., 1997. Myth or Reality? The Long-Run Underperformance of Initial Public Offerings: Evidence from Venture and Non-Venture Capital-Backed Companies. Journal of Finance, Vol. 52, No. 5, pp. 1791-1821.

Casamatta, C., and Haritchabalet, C., 2007. Experience, Screening and Syndication in Venture Capital Investments. Journal of Financial Intermediation, Vol. 16, No. 3, pp. 368-398.

Cestone, G., White, L., and Lerner, J., 2007. The Design of Syndicates in Venture Capital. Unpublished working paper.

Chemmanur, T., and Tian, X., 2009. Peer Monitoring, Syndication, and the Dynamics of Venture Capitalist Interactions. Unpublished working paper.

Chemmanur, T., Krishnan, K., Nandy, D., 2011. How Does Venture Capital Financing Improve Efficiency in Private Firms? A Look beneath the Surface., 2011. Review of Financial Studies, Vol. 24, No.12, pp.4037-4090.

Chuang, Y. and Hsu, P., 2004. FDI, Trade, and Spillover Efficiency: Evidence from China's Manufacturing Sector. Applied Economics, Vol. 36, No. 10, pp. 1103-1115.

Cull, R., Xu, C., and Zhu, T., 2009. Formal Finance and Trade Credit during China's Transition. Journal of Financial Intermediation, Vol. 18, No.2, pp. 173-192.

Davila, A., Foster, G., and Gupta, M., 2003.Venture Capital Financing and the Growth of Startup Firms. Journal of Business Venturing, Vol.18, No.6, pp. 689-708.

Du, J., and Xu, C., 2009. Which Firms Went Public in China? A Study of Financial Market Regulation. World Development, Vol.37, No.4, pp. 812-824.

Feng, Z., 2004. Venture Capital Investment in China. PhD thesis, Pardee Rand Graduate School.

Ghemawat, P. and Spence, M., 1985. Learning Curve Spillovers and Market Performance. The Quarterly Journal of Economics, Vol.100, (Supplement), pp. 839-852.

Gompers, P., and Lerner, J., 1996. The Use of Covenants: An Empirical Analysis of Venture Partnership Agreements. Journal of Law and Economics, Vol. 39, No.2, 463-498.

Gompers, P., and Lerner, J., 2001. The Money of Invention: How Venture Capital Creates New Wealth. Harvard Business Press: Boston, MA.

Guo, D., 2008. Venture Capital Institutions and Venture Capitalists' Investment Activities: An Empirical Study on China. Unpublished working paper. 
Hellmann, T. and Puri, M., 2000, The Interaction between Product Market and Financing Strategy: The Role of Venture Capital. Review of Financial Studies, Vol. 13, No. 4, pp. 959-984.

Hellmann, T. and Puri, M., 2002. Venture Capital and the Professionalization of Start-up Firms: Empirical Evidence. Journal of Finance, Vol. 57, No. 1, pp. 169-197.

Hsieh, C. T. and Klenow, P. J., 2009. Misallocation and Manufacturing TFP in China and India. Quarterly Journal of Economics, Vol. 124, No. 4, pp. 1403-1448.

Hu, A. GZ, Jefferson, G.H, and Qian, J.,2005. R\&D and Technology Transfer: Firm-level Evidence from Chinese Industry. Review of Economics and Statistics, Vol. 87, No.4, pp. 780-786.

Jefferson, G.H., Hu, A.G., and Su, J., 2006. The Sources and Sustainability of China's Economic Growth. Brookings Papers on Economic Activity, Vol. 2006, No.2, pp. 1-47.

Kaplan, S., Sensoy, B., Strömberg, P., 2009. Should Investors Bet on the Jockey or the Horse? Evidence from the Evolution of Firms from Early Business Plans to Public Companies. Journal of Finance, Vol.64, No. 1, pp. 75-115.

Kazmier, L.J., Pohl, N.F., 1984. Basic Statistics for Business and Economics, 2nd Edition. McGraw-Hill, New York.

Kortum, S., and Lerner, J., 2000. Assessing the Contribution of Venture Capital to Innovation. RAND Journal of Economics, Vol.31, No.4, pp. 674-692.

Lee, P. and Wahal, S., 2004. Grandstanding, Certification and the Underpricing of Venture Capital Backed IPOs. Journal of Financial Economics, Vol. 73, No.2, pp. 375-407.

Macmillan, L.C., Siegel, R., and SubbaNarasimha, P., 1985. Criteria Used by Venture Capitalists to Evaluate New Venture Proposals. Journal of Business Venturing, Vol. 1, No.1, pp. 119-128.

Megginson, W.L. and Weiss, K.A., 1991. Venture Capitalist Certification in Initial Public Offerings. Journal of Finance, Vol. 46, No.3, pp. 879-903.

Nahata, R., 2008. Venture Capital Reputation and Investment Performance. Journal of Financial Economics, Vol. 90, No.2, pp. 127-151.

Pfeffer, J., 1996. Competitive Advantage Through People: Unleashing the Power of the Work Force. Harvard Business School Press: Cambridge, MA.

Puri, M., and Zarutskie, R., 2012. On the Life Cycle Dynamics of Venture-Capital and Non-VentureCapital- Financed Firms. The Journal of Finance, Vol.67, No.6, pp. 2247-2293.

Rosenbaum, P.R, and Rubin, D. B., 1983. The Central Role of the Propensity Score in Observational Studies for Causal Effects. Biometrika, Vol. 70, No. 1, pp.41-55.

Sahlman, W., 1990. The Structure and Governance of Venture Capital Organizations. Journal of Financial Economics, Vol. 27, No.2, pp. 473-524.

Spence, M., 1981. The Learning Curve and Competition. The Bell Journal of Economics, Vol.12, No.1, pp. 49-70. 
Soreson, O. and Stuart. T., 2001. Syndication Networks and the Spatial Distribution of Venture Capital Investments. The American Journal of Sociology, Vol. 106, No. 6, pp. 1546-1588.

Tian, X., 2011. The Role of Venture Capital Syndication in Value Creation for Entrepreneurial Firms. Review of Finance, Vol. 16, No. 1, pp. 245-283.

Titman, S., 1984. The Effect of Capital Structure on a Firm's Liquidation Decision. Journal of Financial Economics, Vol. 13, No.1, pp. 137-151.

Zero2IPO, 2007. Annual Report on Venture Capital Investment in China: 2007. Beijing: Zero2IPO Co. Ltd.

Zero2IPO, 2001-2009. Annual Reports on Venture Capital Investment in China: 2001-2009. Beijing: Zero2IPO Co. Ltd. 


\section{Appendix. Interview Data}

We conducted interviews with VCs in Beijing, Shanghai, and Shenzhen between 2005 and 2006. The interviews focused on exploring the management of VCFs and VC investment activities in China, including ex-ante project selection, due diligence process, contract design, and postinvestment monitoring activities. Convenience and snowball sampling strategies were adopted for the interviews. We tried to contact VCs that are very active in China's market. In total, 37 VCs from 34 VCFs were interviewed. Among the 37 VCs, 24 are from 22 FVCFs and 13 are from 12 DVCFs (Table A-1). The majority of FVCFs are from the United States. In addition, 19 of the $22 \mathrm{FVCFs}$ are structured as limited partnerships, and the remaining 3 are structured as limited companies. Meanwhile, the majority of DVCFs are from Beijing, and all of them are structured as limited companies. Despite the small sample size, we cover VCs from some of the most active VCFs in China. The 34 VCFs have invested in over 600 deals, representing more than one third of the total venture capital investment by the number of deals until the end of 2006. The VCs interviewed are mainly from large VCFs measured by fund size; 18 of the 37 VCs are from the top $30 \mathrm{VCFs}$ in China.

Table A-1 Profile of Interviewees

\begin{tabular}{|l|l|l|l|l|l|l|}
\hline $\begin{array}{l}\text { INTER- } \\
\text { VIEWEE }\end{array}$ & $\begin{array}{l}\text { ORGANI- } \\
\text { ZATION }\end{array}$ & $\begin{array}{l}\text { INTERVIEW } \\
\text { METHODS* }\end{array}$ & $\begin{array}{l}\text { LOCATION OF } \\
\text { VCF }\end{array}$ & $\begin{array}{l}\text { FVCF OR } \\
\text { DVCF* }\end{array}$ & $\begin{array}{l}\text { STRUCTURE } \\
\text { OF VCF }\end{array}$ & $\begin{array}{l}\text { POSITION } \\
\text { OF VC }\end{array}$ \\
\hline VC1 & VCF1 & UI\&SI & California & FVCF & LPVCF & Partner \\
\hline VC2 & VCF2 & SI & California & FVCF & LPVCF & $\begin{array}{l}\text { Vice } \\
\text { President }\end{array}$ \\
\hline VC3 & VCF3 & UI\& SI & California & FVCF & LCVCF & $\begin{array}{l}\text { Investment } \\
\text { Manager }\end{array}$ \\
\hline VC4 & VCF4 & 2UI\&SI & Beijing & DVCF & LCVCF & $\begin{array}{l}\text { General } \\
\text { Manager }\end{array}$ \\
\hline VC5 & VCF5 & SI & Beijing & DVCF & LCVCF & $\begin{array}{l}\text { Investment } \\
\text { Manager }\end{array}$ \\
\hline VC6 & VCF6 & SI & London & FVCF & LPVCF & Partner \\
\hline VC7 & VCF7 & SI & Washington & FVCF & LPVCF & $\begin{array}{l}\text { Investment } \\
\text { Manager }\end{array}$ \\
\hline VC8 & VCF8 & SI & Beijing & DVCF & LCVCF & $\begin{array}{l}\text { General } \\
\text { Manager }\end{array}$ \\
\hline VC9 & VCF9 & SI & California & FVCF & LPVCF & Partner \\
\hline VC10 & VCF10 & SI & Cologne & FVCF & LPVCF & $\begin{array}{l}\text { Investment } \\
\text { Manager }\end{array}$ \\
\hline VC11 & VCF11 & SI & California & FVCF & LPVCF & $\begin{array}{l}\text { Vice } \\
\text { President }\end{array}$ \\
\hline VC12 & VCF12 & SI & California & FVCF & LPVCF & $\begin{array}{l}\text { Investment } \\
\text { Manager }\end{array}$ \\
\hline VC13 & VCF13 & SI & Singapore & FVCF & LCVCF & $\begin{array}{l}\text { Vice } \\
\text { President }\end{array}$ \\
\hline VC14 & VCF14 & SI & California & FVCF & LPVCF & Partner \\
\hline VC15 & VCF15 & SI & California & FVCF & LPVCF & Partner \\
\hline VC16 & VCF16 & 2 UI\&SI & California & FVCF & LPVCF & Partner \\
\hline VC17 & VCF16 & UI\&SI & California & FVCF & LPVCF & $\begin{array}{l}\text { Investment } \\
\text { Manager }\end{array}$ \\
\hline
\end{tabular}




\begin{tabular}{|c|c|c|c|c|c|c|}
\hline VC18 & VCF17 & SI & Massachusetts & FVCF & LPVCF & Partner \\
\hline VC19 & VCF18 & SI & Tokyo & FVCF & LPVCF & $\begin{array}{l}\text { Vice } \\
\text { President }\end{array}$ \\
\hline VC20 & VCF19 & SI & New York & FVCF & LPVCF & Partner \\
\hline VC21 & VCF20 & UI\&SI & Beijing & $\overline{D V C F}$ & LCVCF & $\begin{array}{l}\text { Vice } \\
\text { President }\end{array}$ \\
\hline VC22 & VCF20 & SI & Beijing & DVCF & LCVCF & $\begin{array}{l}\text { Investment } \\
\text { Manager }\end{array}$ \\
\hline VC23 & VCF21 & SI & Shanghai & DVCF & LCVCF & $\begin{array}{l}\text { General } \\
\text { Manager }\end{array}$ \\
\hline VC24 & VCF22 & UI\&SI & Shenzhen & DVCF & LCVCF & $\begin{array}{l}\text { General } \\
\text { Manager }\end{array}$ \\
\hline VC25 & VCF23 & SI & Taipei & FVCF & LPVCF & $\begin{array}{l}\text { Vice } \\
\text { President }\end{array}$ \\
\hline VC26 & VCF24 & SI & California & FVCF & LPVCF & Partner \\
\hline VC27 & VCF25 & SI & New York & FVCF & LPVCF & $\begin{array}{l}\text { Investment } \\
\text { Manager }\end{array}$ \\
\hline VC28 & VCF26 & SI & Hong Kong & FVCF & LPVCF & Partner \\
\hline VC29 & VCF27 & SI & Oberhaching & FVCF & LCVCF & $\begin{array}{l}\text { Investment } \\
\text { Manager }\end{array}$ \\
\hline VC30 & VCF28 & SI & Beijing & DVCF & LCVCF & $\begin{array}{l}\text { Investment } \\
\text { manager }\end{array}$ \\
\hline VC31 & VCF29 & SI & Beijing & DVCF & LCVCF & $\begin{array}{l}\text { General } \\
\text { Manager }\end{array}$ \\
\hline VC32 & VCF30 & SI & Beijing & DVCF & LCVCF & $\begin{array}{l}\text { Vice } \\
\text { President }\end{array}$ \\
\hline VC33 & VCF31 & SI & Shanghai & DVCF & LCVCF & $\begin{array}{l}\text { Vice } \\
\text { President }\end{array}$ \\
\hline VC34 & VCF32 & SI & California & FVCF & LPVCF & $\begin{array}{l}\text { Vice } \\
\text { President }\end{array}$ \\
\hline VC35 & VCF33 & SI & New York & FVCF & LPVCF & $\begin{array}{l}\text { Vice } \\
\text { President }\end{array}$ \\
\hline VC36 & VCF34 & SI & Beijing & DVCF & LCVCF & $\begin{array}{l}\text { Investment } \\
\text { manager }\end{array}$ \\
\hline VC37 & VCF21 & SI & Shanghai & DVCF & LCVCF & $\begin{array}{l}\text { Investment } \\
\text { manager }\end{array}$ \\
\hline
\end{tabular}

*: UI: unstructured interviews; SI: semi-structured interviews 
Table A-2 Ex-ante Project Assessment Criteria of VCs in China

\begin{tabular}{|c|c|c|}
\hline Project selection criteria: Likert Scale: $0-4$ & Mean & SD \\
\hline \multicolumn{3}{|l|}{ Group I: Personality of entrepreneur. The entrepreneur: } \\
\hline 1. is honest enough. & 3.68 & 0.475 \\
\hline 2. is capable of sustained intense effort. & 3.65 & 0.485 \\
\hline 3. is able to evaluate and react to risks well. & 3.35 & 0.544 \\
\hline 4. articulates in discussing venture. & 2.88 & 0.409 \\
\hline 5. attends to details. & 2.38 & 0.551 \\
\hline 6. has a personality compatible with mine. & 1.97 & 0.870 \\
\hline 7. has rich social network. & 3.03 & 0.388 \\
\hline \multicolumn{3}{|l|}{ Group II: Capability of entrepreneur. The entrepreneur: } \\
\hline 8 . is thoroughly familiar with the market targeted by the project. & 3.74 & 0.448 \\
\hline 9. has demonstrated leadership ability in past. & 3.21 & 0.410 \\
\hline 10. has a track record relevant to venture. & 2.91 & 0.514 \\
\hline 11. was referred to me by a trustworthy source. & 2.26 & 0.618 \\
\hline 12. has overseas educational and working experience. & 2.09 & 0.933 \\
\hline 13. I am already familiar with the entrepreneur's reputation. & 2.03 & 0.627 \\
\hline \multicolumn{3}{|l|}{ Group III: Characteristics of the product or service } \\
\hline 14. The product is proprietary or can otherwise be protected. & 2.94 & 0.629 \\
\hline 15. The product enjoys demonstrated market acceptance. & 3.26 & 0.511 \\
\hline 16. The product has been developed to the point of a functioning prototype. & 2.18 & 0.576 \\
\hline 17. The product may be described as "high tech." & 2.15 & 0.702 \\
\hline 18. The product has great potentials for export. & 2.03 & 0.460 \\
\hline 19. The product or service is complementary to our other portfolios. & 2.09 & 0.621 \\
\hline \multicolumn{3}{|l|}{ Group IV: Characteristics of the market of the product or service } \\
\hline 20. The target market enjoys a significant growth rate. & 3.71 & 0.462 \\
\hline 21. The venture will stimulate an existing market. & 2.35 & 0.485 \\
\hline 22. The venture is in an industry with which I am familiar. & 2.06 & 0.547 \\
\hline 23. There is little threat of competition during the first three years. & 2.82 & 0.387 \\
\hline 24. The venture will create a new market. & 1.94 & 0.489 \\
\hline 25. The market size is scalable. & 3.18 & 0.576 \\
\hline \multicolumn{3}{|l|}{ Group V: Financial considerations with this project } \\
\hline 26. I require a return equal to at least 10 times my investment within 5-10 years. & 3.24 & 0.606 \\
\hline 27. I require an investment that can easily be made liquid (e.g., taken public or acquired). & 2.94 & 0.422 \\
\hline 28. I require a return equal to at least 10 times my investment within at least 5 years. & 2.76 & 0.431 \\
\hline 29. I will not be expected to make subsequent investment. & 1.94 & 0.600 \\
\hline
\end{tabular}




\begin{tabular}{|c|c|c|}
\hline 30. I will not participate in latter rounds of investment. & 1.24 & 0.606 \\
\hline 31. It is easy to find further investors or bank loans for the project. & 2.38 & 0.511 \\
\hline \multicolumn{3}{|l|}{ Group VI: Geographical considerations with this project } \\
\hline 32. The project is located in capital city or other major cities in China. & 2.26 & 0.511 \\
\hline 33. The project is located within 50 miles from my office. & 1.24 & 0.431 \\
\hline 34. It is easy to access needed human resources in the location. & 3.00 & 0.492 \\
\hline 35. Local public policy is friendly to SMEs and venture industry. & 2.97 & 0.460 \\
\hline \multicolumn{3}{|c|}{$\begin{array}{l}\text { Group IV: Features of the management team. (Please score } 1 \text { for the single item below that you suggest the mos } \\
\text { essential one for the venture to go forward.) }\end{array}$} \\
\hline 36. The project is initiated by one person, and he/she has relevant experience on the idea. & $5.9 \%$ & \\
\hline $\begin{array}{l}\text { 37. The project is initiated by more than one person, all having similar relevant } \\
\text { experience. }\end{array}$ & $8.8 \%$ & \\
\hline $\begin{array}{l}\text { 38. The venture is initiated by more than one person, the individuals constituting a } \\
\text { functionally balanced management team. }\end{array}$ & $58.8 \%$ & \\
\hline 39. None of the above factors are essential for the venture to go forward. & $26.5 \%$ & \\
\hline
\end{tabular}

Table A-3 Ten Essential Project Selection Criteria Identified by VCs

\begin{tabular}{|l|l|l|}
\hline 1. The entrepreneur is thoroughly familiar with the market targeted by the project. & 25 & 73.5 \\
\hline 2. The entrepreneur is capable of sustained intense effort. & 23 & 67.6 \\
\hline 3. The entrepreneur is honest enough. & 22 & 64.7 \\
\hline 4. The target market enjoys a significant growth rate. & 20 & 58.8 \\
\hline 5. The entrepreneur is able to evaluate and react to risks well. & 13 & 38.2 \\
\hline 6. I require a return equal to at least 10 times my investment within 5-10 years. & 11 & 32.4 \\
\hline 7. The product enjoys demonstrated market acceptance. & 10 & 29.4 \\
\hline 8. The market size is scalable. & 9 & 26.5 \\
\hline 9. The product is proprietary or can otherwise be protected. & 6 & 17.6 \\
\hline 10. Local public policy is friendly to SMEs and venture industry. & 4 & 11.8 \\
\hline
\end{tabular}




\begin{tabular}{|c|c|c|c|}
\hline Industry & Freq. & Percent & Cum. \\
\hline \multicolumn{4}{|l|}{ Traditional Industries } \\
\hline Mining of non-metal Minerals & 1 & $0.39 \%$ & $0.39 \%$ \\
\hline Argo-Food Processing & 10 & $3.88 \%$ & $4.26 \%$ \\
\hline Food Manufacturing & 9 & $3.49 \%$ & $7.75 \%$ \\
\hline Beverage Manufacturing & 9 & $3.49 \%$ & $11.24 \%$ \\
\hline Textile & 3 & $1.16 \%$ & $12.40 \%$ \\
\hline Garment and Shoes & 4 & $1.55 \%$ & $13.95 \%$ \\
\hline Leather, Fur and Feather Products & 3 & $1.16 \%$ & $15.12 \%$ \\
\hline Timber Processing & 2 & $0.78 \%$ & $15.89 \%$ \\
\hline Furniture & 3 & $1.16 \%$ & $17.05 \%$ \\
\hline Paper and Paper Products & 5 & $1.94 \%$ & $18.99 \%$ \\
\hline Printing & 1 & $0.39 \%$ & $19.38 \%$ \\
\hline Stationary and Sport Products & 2 & $0.78 \%$ & $20.16 \%$ \\
\hline Petroleum Processing & 2 & $0.78 \%$ & $20.93 \%$ \\
\hline Chemical Fibers & 1 & $0.39 \%$ & $21.32 \%$ \\
\hline Plastic Products & 3 & $1.16 \%$ & $22.48 \%$ \\
\hline Non-metallic Mineral Products & 17 & $6.59 \%$ & $29.07 \%$ \\
\hline Ferrous Metal Smelting and Processing & 2 & $0.78 \%$ & $29.84 \%$ \\
\hline Non-Ferrous Metal Smelting and Processing & 5 & $1.94 \%$ & $31.78 \%$ \\
\hline Fabricated Metal Products & 7 & $2.71 \%$ & $34.50 \%$ \\
\hline Artwork and Other & 7 & $2.71 \%$ & $37.21 \%$ \\
\hline Electricity and Heating & 2 & $0.78 \%$ & $37.98 \%$ \\
\hline Transportation Machinery & 8 & $3.10 \%$ & $41.09 \%$ \\
\hline \multicolumn{4}{|l|}{ High-Tech Industries } \\
\hline General Machinery & 20 & $7.75 \%$ & $48.84 \%$ \\
\hline Special Machinery & 16 & $6.20 \%$ & $55.04 \%$ \\
\hline Electrical Machinery & 25 & $9.69 \%$ & $64.73 \%$ \\
\hline Tele-Communication and Computer & 29 & $11.24 \%$ & $75.97 \%$ \\
\hline Instrumentation & 12 & $4.65 \%$ & $80.62 \%$ \\
\hline Chemical Materials and Chemical Products & 30 & $11.63 \%$ & $92.25 \%$ \\
\hline Pharmaceutical Products & 20 & $7.75 \%$ & $100.00 \%$ \\
\hline Total & 258 & $100 \%$ & $100 \%$ \\
\hline
\end{tabular}


Table 2 Summary Statistics of VC-backed Firms

\begin{tabular}{|c|c|c|c|c|c|}
\hline Variable & Obs & Mean & Std. Dev. & Min & Max \\
\hline Total Asset (10000 RMB) & 258 & 644821.80 & 1129206 & 2826 & 6214909 \\
\hline Total Equity (10000 RMB) & 258 & 194560.40 & 212533 & 0.00 & 681298 \\
\hline Total Sales (10000 RMB) & 258 & 502360.90 & 693020 & 5290 & 2742586 \\
\hline Firm size & 258 & 970.36 & 1371.91 & 14 & 6748 \\
\hline ROS & 258 & 0.10 & 0.17 & -0.80 & 0.47 \\
\hline ROE & 257 & 0.23 & 0.50 & -1.74 & 4.80 \\
\hline Labor Productivity & 258 & 74.69 & 108.39 & -85.63 & 447.47 \\
\hline $\mathrm{R} \& \mathrm{D}$ & 168 & 0.01 & 0.03 & 0.00 & 0.12 \\
\hline Sales Growth & 217 & 0.31 & 0.53 & -0.58 & 2.75 \\
\hline Leverage & 258 & 0.55 & 0.22 & 0.03 & 1.83 \\
\hline State Ownership & 206 & 0.02 & 0.11 & 0.00 & 0.97 \\
\hline Employee Treatment & 207 & 25.53 & 17.54 & 4.09 & 95.44 \\
\hline Firm Age & 258 & 9.31 & 9.22 & 0 & 51 \\
\hline
\end{tabular}

Variables are winsorized at the $1 \%$ and $99 \%$ levels.

Table 3 T-test for the Performance and R\&D of VC-backed and Non-VC-backed Firms

\begin{tabular}{|c|c|c|c|c|c|}
\hline $\mathrm{t}=0$ & VC_backed firms & Control group & difference & t-statistics & z-statistics \\
\hline ROS & 0.092 & 0.050 & 0.042 & $3.488 * * *$ & $3.324 * * *$ \\
\hline ROE & 0.236 & 0.194 & 0.043 & 0.807 & $1.654 *$ \\
\hline Sales Growth & 0.378 & 0.135 & 0.243 & $3.259 * * *$ & $3.418 * * *$ \\
\hline Labor Productivity & 71.913 & 31.695 & 40.219 & $4.730 * * *$ & 4.758 \\
\hline R\&D & 0.019 & 0.006 & 0.013 & $3.068 * * *$ & $5.004 * * *$ \\
\hline $\mathrm{t}=1$ & VC_backed firms & Control group & difference & t-statistics & z-statistics \\
\hline ROS & 0.105 & 0.056 & 0.049 & $5.167 * * *$ & $4.442 * * *$ \\
\hline $\mathrm{ROE}$ & 0.309 & 0.226 & 0.084 & $1.802 *$ & $2.371 * *$ \\
\hline Sales Growth & 0.233 & 0.201 & 0.201 & 0.599 & 0.579 \\
\hline Labor Productivity & 74.730 & 33.023 & 41.707 & $6.279 * * *$ & $6.121 * * *$ \\
\hline $\mathrm{R} \& \mathrm{D}$ & 0.013 & 0.007 & 0.006 & $2.032 * *$ & $2.972 * * *$ \\
\hline $\mathrm{t}=2$ & VC_backed firms & Control group & difference & t-statistics & z-statistics \\
\hline ROS & 0.127 & 0.055 & 0.072 & $8.689 * * *$ & $8.034 * * *$ \\
\hline $\mathrm{ROE}$ & 0.267 & 0.223 & 0.044 & 1.242 & $2.953 * * *$ \\
\hline Sales Growth & 0.513 & 0.343 & 0.171 & $2.440 * *$ & $3.043 * * *$ \\
\hline Labor Productivity & 81.482 & 26.081 & 26.081 & $10.601 * * *$ & $9.353 * * *$ \\
\hline $\mathrm{R} \& \mathrm{D}$ & 0.016 & 0.005 & 0.011 & $4.254 * * *$ & $6.474 * * *$ \\
\hline
\end{tabular}

All observations are at the firm-year level. ***,**, and * represent statistical significance at the $1 \%, 5 \%$, and $10 \%$ levels, respectively. Statistical significance for differences of means and medians differences correspond to t-tests and rank-sum tests, respectively. 


\section{Table 4 The Performance and R\&D of VC-backed Firms and Non-VC-backed Firms}

This is a series of random effect panel regressions for the profitability, sales growth, labor productivity and R\&D of VC-backed and non-VC-backed firms. The observations are firm-year units of the sampled 258 VC-backed firms and their non-VC-backed counterparts (one to five pairs matched by location and industry of the firm). The dependent variables include ROS, ROE, Sales Growth, Labor Productivity and $R \& D$ expenditure over total sales. Independent variables include VC Dummy, a dummy variable that equals to one if the firm is backed by venture investment and zero if otherwise. Control variables include employee treatment, which is measured by the average salary of the employees; Leverage, which is measured by the total debts over total assets; State Ownership, which is measured by the total state shareholding over total equity; firm size, which is measured by the total number of employees; and firm age, which is the age of the firm.

(1)

(2)

(3)

(4)

(5)

\begin{tabular}{|c|c|c|c|c|c|}
\hline & ROS & ROE & Sales Growth & Labor Productivity & $\mathrm{R} \& \mathrm{D}$ \\
\hline \multirow[t]{2}{*}{ VC Dummy } & $0.028 * * *$ & $0.049 * * *$ & $0.195^{*}$ & $28.290 * * *$ & $0.008 * * *$ \\
\hline & $(0.006)$ & $(0.016)$ & $(0.111)$ & $(3.054)$ & $(0.001)$ \\
\hline \multirow[t]{2}{*}{ Employee Treatment } & $0.0004 * * *$ & $-0.0008 * *$ & 0.0009 & $1.1410 * * *$ & $0.0002 * * *$ \\
\hline & $(0.0001)$ & $(0.0003)$ & $(0.0020)$ & $(0.0461)$ & $(0.0000)$ \\
\hline \multirow[t]{2}{*}{ Leverage } & $-0.079 * * *$ & $0.461 * * *$ & 0.010 & $-29.740 * * *$ & $-0.003 *$ \\
\hline & $(0.006)$ & $(0.022)$ & $(0.147)$ & $(3.267)$ & $(0.002)$ \\
\hline \multirow[t]{2}{*}{ State Ownership } & $-0.035 * * *$ & $0.055^{*}$ & $-0.515^{* *}$ & $-14.54 * * *$ & 0.002 \\
\hline & $(0.009)$ & $(0.034)$ & $(0.217)$ & $(4.903)$ & $(0.003)$ \\
\hline \multirow[t]{2}{*}{ Firm Size } & $0.010 * * *$ & 0.002 & $0.121 * * *$ & $-2.194 * * *$ & $0.001 * *$ \\
\hline & $(0.002)$ & $(0.005)$ & $(0.034)$ & $(0.818)$ & $(0.000)$ \\
\hline \multirow[t]{2}{*}{ Firm Age } & $-0.001 * * *$ & $-0.002 * * *$ & $-0.010 * * *$ & -0.000 & $0.000 * *$ \\
\hline & $(0.000)$ & $(0.001)$ & $(0.004)$ & $(0.091)$ & $(0.000)$ \\
\hline \multirow[t]{2}{*}{ Constant } & $0.038 * * *$ & $0.048^{*}$ & -0.046 & $29.760 * * *$ & -0.003 \\
\hline & $(0.008)$ & $(0.027)$ & $(0.185)$ & $(4.410)$ & $(0.002)$ \\
\hline Firm and Year Effect & Yes & Yes & Yes & Yes & Yes \\
\hline $\mathrm{N}$ & 6925 & 6929 & 5663 & 6929 & 3127 \\
\hline $\mathrm{P}$-value for Chi2 & 0.000 & 0.000 & 0.000 & 0.000 & 0.000 \\
\hline
\end{tabular}

Standard errors are in parentheses. $* * *, * *$, and $*$ represent statistical significance at the $1 \%, 5 \%$, and $10 \%$ levels, respectively. 


\section{Table 5 Logit Regressions for Selection of Venture Capital Investment}

This is a series of Logit regressions for a sample of 258 VC-backed firms and their non-VC-backed counterparts (1-5 pairs matched by location and industry of the firms). The dependent variable is VC Dummy, a dummy variable that equals to one if the firm is backed by venture investment and zero if otherwise. Independent variables include ROS, ROE, Sales Growth, Labor Productivity and $R \& D$ expenditure over total sales in the year when the firm received venture investment. Control variables include Leverage, which is measured by the total debts over total assets; State Ownership, which is measured by the total state shareholding over total equity; firm size, which is measured by the total number of employees; and firm age, which is the age of the firm.

Dependent Variable: VC Dummy

\begin{tabular}{|c|c|c|c|c|c|c|c|}
\hline & (1) & (2) & (3) & (4) & (5) & (6) & (7) \\
\hline \multirow[t]{2}{*}{ ROS } & $5.103 * * *$ & & & & & $2.797 * *$ & 2.031 \\
\hline & $(0.813)$ & & & & & $(1.158)$ & $(1.528)$ \\
\hline \multirow[t]{2}{*}{ ROE } & & $2.189 * * *$ & & & & $0.771^{*}$ & $1.097 *$ \\
\hline & & $(0.369)$ & & & & $(0.482)$ & $(0.575)$ \\
\hline \multirow[t]{2}{*}{ Sales Growth } & & & $0.228 * *$ & & & 0.167 & $0.248 * *$ \\
\hline & & & $(0.095)$ & & & $(0.111)$ & $(0.125)$ \\
\hline \multirow[t]{2}{*}{ Labor Productivity } & & & & $0.011 * * *$ & & $0.009 * * *$ & $0.010 * * *$ \\
\hline & & & & $(0.001)$ & & $(0.001)$ & $(0.002)$ \\
\hline \multirow[t]{2}{*}{$\mathrm{R} \& \mathrm{D}$} & & & & & $23.540^{* * *}$ & & $21.330^{* * *}$ \\
\hline & & & & & $(5.172)$ & & $(5.829)$ \\
\hline \multirow[t]{2}{*}{ Leverage } & $1.146 * * *$ & 0.073 & 0.428 & $0.994 * *$ & 0.696 & $1.186^{* *}$ & $1.595 * *$ \\
\hline & $(0.404)$ & $(0.390)$ & $(0.414)$ & $(0.412)$ & $(0.444)$ & $(0.518)$ & $(0.637)$ \\
\hline \multirow[t]{2}{*}{ State Ownership } & -0.690 & -0.308 & -0.380 & -0.055 & -0.789 & -0.505 & -0.495 \\
\hline & $(0.733)$ & $(0.728)$ & $(0.706)$ & $(0.715)$ & $(1.025)$ & $(0.769)$ & (1.119) \\
\hline \multirow[t]{2}{*}{ Firm Size } & $0.001 * * *$ & $0.001 * * *$ & $0.001 * * *$ & $0.001 * * *$ & $0.001 * * *$ & $0.001 * * *$ & $0.001 * * *$ \\
\hline & $(0.000)$ & $(0.000)$ & $(0.000)$ & $(0.000)$ & $(0.000)$ & $(0.000)$ & $(0.000)$ \\
\hline \multirow[t]{2}{*}{ Firm Age } & $-0.024 * *$ & $-0.021^{*}$ & $-0.019^{*}$ & $-0.022 * *$ & $-0.036 * *$ & -0.015 & $-0.027^{*}$ \\
\hline & $(0.011)$ & $(0.012)$ & $(0.012)$ & $(0.011)$ & $(0.014)$ & $(0.012)$ & $(0.015)$ \\
\hline \multirow[t]{2}{*}{ Constant } & $-2.754 * * *$ & $-2.352 * * *$ & $-2.087 * * *$ & $-2.763 * * *$ & $-2.221 * * *$ & $-3.277 * * *$ & $-3.646^{* * *}$ \\
\hline & $(0.263)$ & $(0.228)$ & $(0.247)$ & $(0.257)$ & $(0.267)$ & $(0.330)$ & $(0.414)$ \\
\hline $\mathrm{N}$ & 1118 & 1119 & 930 & 1118 & 847 & 929 & 709 \\
\hline pseudo R-sq & 0.151 & 0.151 & 0.119 & 0.193 & 0.143 & 0.217 & 0.263 \\
\hline $\mathrm{P}$-value for $\mathrm{Chi} 2$ & 0.000 & 0.000 & 0.000 & 0.000 & 0.000 & 0.000 & 0.000 \\
\hline
\end{tabular}

Standard errors are in parentheses. $* * *, * *$, and $*$ represent statistical significance at the $1 \%, 5 \%$, and $10 \%$ levels, respectively. 


\section{Table 6 Changes of Performance and R\&D of VC-backed and Non-VC-backed Firms (Matched by PSM)}

This is a series of random effect panel regressions for the profitability, sales growth, labor productivity and R\&D of VC-backed and non-VC-backed firms. The observations are firm-year units of the sampled 258 VC-backed firms and their non-VC-backed counterparts (1-5 pairs) matched by Propensity Score Matching (PSM). We use location, industry and ROE as the main matching criteria. The dependent variables include ROS, ROE, Sales Growth, Labor Productivity and R\&D expenditure over total sales. Independent variables include VC Dummy, a dummy variable that is equal to 1 if the firm is backed by venture investment and is equal to 0 if otherwise; VC Entry, a dummy variable that is equal to 0 for the period before the investment is made and is equal to 1 for the period after the investment is made; VC Post, which is an interaction term of VC Dummy and VC Entry. All control variables are the same to those of Table 4 .

\begin{tabular}{|c|c|c|c|c|c|}
\hline & (1) & (2) & (3) & (4) & $(5)$ \\
\hline & ROS & ROE & Sales Growth & Labor Productivity & $\mathrm{R} \& \mathrm{D}$ \\
\hline \multirow[t]{2}{*}{ VC Dummy } & $0.040 * * *$ & -0.021 & $0.285^{* *}$ & $26.150 * * *$ & $0.009 * * *$ \\
\hline & $(0.008)$ & $(0.039)$ & $(0.124)$ & $(4.202)$ & $(0.001)$ \\
\hline \multirow[t]{2}{*}{ VC Entry } & $-0.017 * * *$ & $-0.073 * * *$ & -0.044 & $-3.738^{*}$ & 0.001 \\
\hline & $(0.004)$ & $(0.024)$ & $(0.087)$ & $(2.138)$ & $(0.001)$ \\
\hline \multirow[t]{2}{*}{ VC Post } & $0.023 * * *$ & $0.079^{*}$ & -0.249 & $17.170 * * *$ & 0.003 \\
\hline & $(0.008)$ & $(0.048)$ & $(0.167)$ & (4.317) & $(0.002)$ \\
\hline \multirow[t]{2}{*}{ Employee Treatment } & $0.000 * *$ & 0.001 & $0.005^{* *}$ & $1.125^{* * *}$ & $0.000 * * *$ \\
\hline & $(0.000)$ & $(0.001)$ & $(0.003)$ & $(0.069)$ & $(0.000)$ \\
\hline \multirow[t]{2}{*}{ Leverage } & $-0.083 * * *$ & $0.746 * * *$ & 0.048 & $-38.120 * * *$ & -0.002 \\
\hline & $(0.009)$ & $(0.049)$ & $(0.171)$ & $(4.631)$ & $(0.002)$ \\
\hline \multirow[t]{2}{*}{ State Ownership } & $-0.038 * * *$ & -0.085 & 0.150 & -12.120 & 0.000 \\
\hline & $(0.015)$ & $(0.082)$ & $(0.291)$ & $(7.676)$ & $(0.005)$ \\
\hline \multirow[t]{2}{*}{ Firm Size } & $0.011 * * *$ & $-0.019 *$ & $0.074 * *$ & $-2.000 *$ & -0.000 \\
\hline & $(0.002)$ & $(0.011)$ & $(0.035)$ & $(1.129)$ & $(0.000)$ \\
\hline \multirow[t]{2}{*}{ Firm Age } & $-0.001 * *$ & 0.001 & $-0.008^{*}$ & -0.008 & 0.000 \\
\hline & $(0.000)$ & $(0.001)$ & $(0.004)$ & $(0.137)$ & $(0.000)$ \\
\hline \multirow[t]{2}{*}{ Constant } & $0.028 * *$ & 0.024 & -0.005 & $35.040 * * *$ & 0.002 \\
\hline & $(0.012)$ & $(0.064)$ & $(0.213)$ & $(6.390)$ & $(0.002)$ \\
\hline Firm and Year Effect & Yes & Yes & Yes & Yes & Yes \\
\hline $\mathrm{N}$ & 4142 & 4143 & 3109 & 4143 & 1865 \\
\hline P-value for Chi 2 & 0.000 & 0.000 & 0.001 & 0.000 & 0.000 \\
\hline
\end{tabular}

Standard errors are in parentheses. $* * *, * *$, and $*$ represent statistical significance at the $1 \%, 5 \%$, and $10 \%$ levels, respectively. 


\section{Table 7 Heckman 2SLS Regressions for Changes of Performance and R\&D of VC-backed and Non-VC-backed Firms}

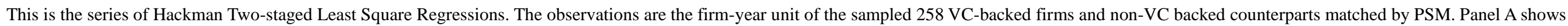

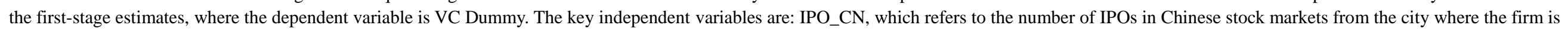

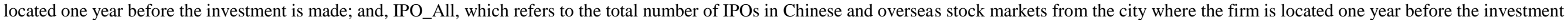

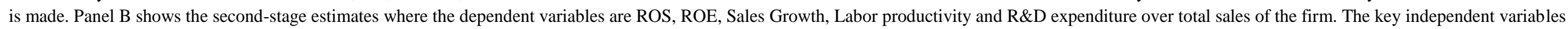
are VC Dummy instrumented by IPO_CN and IPO_All respectively. All control variables are the same to those of Table 4.

\section{Panel A: The First-Stage Estimates}

\begin{tabular}{|c|c|c|c|c|c|c|c|c|c|c|}
\hline \multicolumn{11}{|c|}{ Independent Variable: VC Dummy (Is the firm backed by venture investment?) } \\
\hline & $(1)$ & (2) & (3) & (4) & $(5)$ & (6) & (7) & $(8)$ & (9) & (10) \\
\hline IPO_CN & $\begin{array}{c}0.190 * * * \\
(0.024)\end{array}$ & $\begin{array}{c}0.190 * * * \\
(0.024)\end{array}$ & $\begin{array}{c}0.187 * * * \\
(0.027)\end{array}$ & $\begin{array}{c}0.190 * * * \\
(0.024)\end{array}$ & $\begin{array}{c}0.232 * * * \\
(0.035)\end{array}$ & & & & & \\
\hline IPO_All & & & & & & $\begin{array}{c}0.100^{* * * *} \\
(0.013)\end{array}$ & $\begin{array}{c}0.100 * * * \\
(0.013)\end{array}$ & $\begin{array}{c}0.088 * * * * \\
(0.014)\end{array}$ & $\begin{array}{c}0.100 * * * \\
(0.013)\end{array}$ & $\begin{array}{c}0.116^{* * * *} \\
(0.019)\end{array}$ \\
\hline VC Entry & $\begin{array}{c}-1.011 * * * \\
(0.088)\end{array}$ & $\begin{array}{c}-1.011 * * * \\
(0.088)\end{array}$ & $\begin{array}{c}-1.069 * * * \\
(0.095)\end{array}$ & $\begin{array}{c}-1.011 * * * \\
(0.088)\end{array}$ & $\begin{array}{c}-1.317 * * * \\
(0.118)\end{array}$ & $\begin{array}{c}-1.002 * * * \\
(0.088)\end{array}$ & $\begin{array}{c}-1.002 * * * \\
(0.088)\end{array}$ & $\begin{array}{c}-1.059 * * * \\
(0.095)\end{array}$ & $\begin{array}{c}-1.002 * * * \\
(0.088)\end{array}$ & $\begin{array}{c}-1.298 * * * \\
(0.118)\end{array}$ \\
\hline Employee Treatment & $\begin{array}{c}0.034 * * * \\
(0.003)\end{array}$ & $\begin{array}{c}0.034 * * * \\
(0.003)\end{array}$ & $\begin{array}{c}0.037 * * * \\
(0.003)\end{array}$ & $\begin{array}{c}0.034 * * * \\
(0.003)\end{array}$ & $\begin{array}{c}0.029 * * * \\
(0.004)\end{array}$ & $\begin{array}{c}0.033 * * * \\
(0.003)\end{array}$ & $\begin{array}{c}0.033 * * * \\
(0.003)\end{array}$ & $\begin{array}{c}0.036 * * * \\
(0.003)\end{array}$ & $\begin{array}{c}0.033 * * * \\
(0.003)\end{array}$ & $\begin{array}{c}0.029 * * * \\
(0.004)\end{array}$ \\
\hline Leverage & $\begin{array}{l}-0.080 \\
(0.171)\end{array}$ & $\begin{array}{l}-0.080 \\
(0.171)\end{array}$ & $\begin{array}{c}0.004 \\
(0.200)\end{array}$ & $\begin{array}{l}-0.080 \\
(0.171)\end{array}$ & $\begin{array}{l}-0.384 \\
(0.248)\end{array}$ & $\begin{array}{l}-0.060 \\
(0.171)\end{array}$ & $\begin{array}{l}-0.059 \\
(0.171)\end{array}$ & $\begin{array}{c}0.001 \\
(0.200)\end{array}$ & $\begin{array}{l}-0.059 \\
(0.171)\end{array}$ & $\begin{array}{l}-0.354 \\
(0.248)\end{array}$ \\
\hline State Ownership & $\begin{array}{c}-1.012 * * * \\
(0.304)\end{array}$ & $\begin{array}{c}-1.019 * * * \\
(0.304)\end{array}$ & $\begin{array}{c}-0.970 * * * \\
(0.365)\end{array}$ & $\begin{array}{c}-1.019 * * * \\
(0.304)\end{array}$ & $\begin{array}{l}-0.792 \\
(0.588)\end{array}$ & $\begin{array}{c}-1.006 * * * \\
(0.305)\end{array}$ & $\begin{array}{c}-1.012 * * * \\
(0.305)\end{array}$ & $\begin{array}{c}-1.008 * * * \\
(0.367)\end{array}$ & $\begin{array}{c}-1.012 * * * \\
(0.305)\end{array}$ & $\begin{array}{l}-0.839 \\
(0.590)\end{array}$ \\
\hline Firm Size & $\begin{array}{c}0.658 * * * \\
(0.032)\end{array}$ & $\begin{array}{c}0.659 * * * \\
(0.032)\end{array}$ & $\begin{array}{c}0.645^{* * *} * \\
(0.036)\end{array}$ & $\begin{array}{c}0.659 * * * \\
(0.032)\end{array}$ & $\begin{array}{c}0.666 * * * \\
(0.046)\end{array}$ & $\begin{array}{c}0.662 * * * \\
(0.032)\end{array}$ & $\begin{array}{c}0.662 * * * \\
(0.032)\end{array}$ & $\begin{array}{c}0.646 * * * \\
(0.036)\end{array}$ & $\begin{array}{c}0.662 * * * \\
(0.032)\end{array}$ & $\begin{array}{c}0.664 * * * \\
(0.046)\end{array}$ \\
\hline Firm Age & $\begin{array}{c}-0.020 * * * \\
(0.004)\end{array}$ & $\begin{array}{c}-0.020 * * * \\
(0.004)\end{array}$ & $\begin{array}{c}-0.018^{* * *} \\
(0.005)\end{array}$ & $\begin{array}{c}-0.020^{* * * *} \\
(0.004)\end{array}$ & $\begin{array}{c}-0.013 * * \\
(0.007)\end{array}$ & $\begin{array}{c}-0.020^{* * *} \\
(0.004)\end{array}$ & $\begin{array}{c}-0.020 * * * \\
(0.004)\end{array}$ & $\begin{array}{c}-0.018^{* * *} \\
(0.005)\end{array}$ & $\begin{array}{c}-0.020 * * * \\
(0.004)\end{array}$ & $\begin{array}{c}-0.013^{*} \\
(0.007)\end{array}$ \\
\hline Constant & $\begin{array}{c}-4.664 * * * \\
(0.209)\end{array}$ & $\begin{array}{c}-4.665 * * * \\
(0.209)\end{array}$ & $\begin{array}{c}-4.648^{* * *} \\
(0.208)\end{array}$ & $\begin{array}{c}-4.665^{* * *} \\
(0.209)\end{array}$ & $\begin{array}{c}-4.059 * * * \\
(0.292)\end{array}$ & $\begin{array}{c}-4.677 * * * \\
(0.209)\end{array}$ & $\begin{array}{c}-4.678 * * * \\
(0.209)\end{array}$ & $\begin{array}{c}-4.609 * * * \\
(0.247)\end{array}$ & $\begin{array}{c}-4.678 * * * \\
(0.209)\end{array}$ & $\begin{array}{c}-4.080 * * * \\
(0.291)\end{array}$ \\
\hline $\mathrm{N}$ & 4142 & 4143 & 4145 & 4143 & 1865 & 4142 & 4143 & 3110 & 4143 & 1865 \\
\hline Sampling & ROS & ROE & Sales Growth & $\begin{array}{c}\text { Labor } \\
\text { Productivity }\end{array}$ & $\mathrm{R} \& \mathrm{D}$ & ROS & ROE & Sales Growth & $\begin{array}{c}\text { Labor } \\
\text { Productivity }\end{array}$ & $\mathrm{R} \& \mathrm{D}$ \\
\hline pseudo R-sq & 0.186 & 0.187 & 0.186 & 0.187 & 0.229 & 0.187 & 0.187 & 0.200 & 0.187 & 0.227 \\
\hline $\mathrm{P}$-value for Chi2 & 0.000 & 0.000 & 0.000 & 0.000 & 0.000 & 0.000 & 0.000 & 0.000 & 0.000 & 0.000 \\
\hline
\end{tabular}

Standard errors are in parentheses. $* * *, * *$, and $*$ represent statistical significance at the $1 \%, 5 \%$, and $10 \%$ levels, respectively. 
Panel B: The Second-stage Estimates with VC Treatment Effect Instrumented

\begin{tabular}{|c|c|c|c|c|c|c|c|c|c|c|}
\hline & $\begin{array}{c}(1) \\
\text { ROS }\end{array}$ & $\begin{array}{c}(2) \\
\mathrm{ROE}\end{array}$ & $\begin{array}{c}\text { (3) } \\
\text { Sales Growth }\end{array}$ & $\begin{array}{c}(4) \\
\text { Labor } \\
\text { Productivity }\end{array}$ & $\begin{array}{c}(5) \\
R \& D\end{array}$ & $\begin{array}{c}6) \\
\text { ROS }\end{array}$ & $\begin{array}{c}(7) \\
\text { ROE }\end{array}$ & $\begin{array}{c}\text { (8) } \\
\text { Sales } \\
\text { Growth }\end{array}$ & $\begin{array}{c}(9) \\
\text { Labor } \\
\text { Productivity }\end{array}$ & $\begin{array}{l}(10) \\
R \& D\end{array}$ \\
\hline $\begin{array}{l}\text { VC Dummy } \\
\text { (IVed by IPO_CN) }\end{array}$ & $\begin{array}{c}0.091 * * * \\
(0.030)\end{array}$ & $\begin{array}{c}-0.327 * * \\
(0.166)\end{array}$ & $\begin{array}{l}-0.648 \\
(0.522)\end{array}$ & $\begin{array}{l}36.490 * * \\
(15.620)\end{array}$ & $\begin{array}{c}0.043 * * * \\
(0.007)\end{array}$ & & & & & \\
\hline $\begin{array}{l}\text { VC Dummy } \\
\text { (IVed by IPO_ALL) }\end{array}$ & & & & & & $\begin{array}{l}0.074 * * * \\
(0.026)\end{array}$ & $\begin{array}{l}-0.133 \\
(0.146)\end{array}$ & $\begin{array}{l}-0.653 \\
(0.568)\end{array}$ & $\begin{array}{l}22.150 * \\
(13.320)\end{array}$ & $\begin{array}{c}0.039 * * * \\
(0.006)\end{array}$ \\
\hline VC Entry & $\begin{array}{l}-0.006 \\
(0.009)\end{array}$ & $\begin{array}{c}-0.163^{* * *} \\
(0.049)\end{array}$ & $\begin{array}{l}-0.136 \\
(0.173)\end{array}$ & $\begin{array}{l}-2.470 \\
(4.484)\end{array}$ & $\begin{array}{c}0.005^{* *} \\
(0.002)\end{array}$ & $\begin{array}{l}-0.008 \\
(0.008)\end{array}$ & $\begin{array}{c}-0.134 * * * \\
(0.047)\end{array}$ & $\begin{array}{l}-0.124 \\
(0.177)\end{array}$ & $\begin{array}{l}-4.822 \\
(4.244)\end{array}$ & $\begin{array}{l}0.004^{*} \\
(0.002)\end{array}$ \\
\hline VC Post & $\begin{array}{l}0.038^{*} \\
(0.024)\end{array}$ & $\begin{array}{l}0.255^{*} \\
(0.137)\end{array}$ & $\begin{array}{l}-0.531 \\
(0.481)\end{array}$ & $\begin{array}{c}34.940 * * * \\
(12.310)\end{array}$ & $\begin{array}{c}0.013 * * \\
(0.006)\end{array}$ & $\begin{array}{c}0.035 \\
(0.023)\end{array}$ & $\begin{array}{c}0.275^{* *} \\
(0.134)\end{array}$ & $\begin{array}{l}-0.590 \\
(0.493)\end{array}$ & $\begin{array}{c}34.930 * * * \\
(11.990)\end{array}$ & $\begin{array}{c}0.013^{* *} \\
(0.006)\end{array}$ \\
\hline $\begin{array}{l}\text { Employee } \\
\text { Treatment }\end{array}$ & $\begin{array}{c}0.000 \\
(0.000)\end{array}$ & $\begin{array}{l}0.003 * \\
(0.001)\end{array}$ & $\begin{array}{c}0.013 * * * \\
(0.005)\end{array}$ & $\begin{array}{c}0.846^{* * *} \\
(0.134)\end{array}$ & $\begin{array}{c}0.000 * * * \\
(0.000)\end{array}$ & $\begin{array}{c}0.000 \\
(0.000)\end{array}$ & $\begin{array}{c}0.001 \\
(0.001)\end{array}$ & $\begin{array}{c}0.013 * * * \\
(0.005)\end{array}$ & $\begin{array}{c}0.949 * * * \\
(0.120)\end{array}$ & $\begin{array}{c}0.000 * * * \\
(0.000)\end{array}$ \\
\hline Leverage & $\begin{array}{c}-0.087 * * * \\
(0.009)\end{array}$ & $\begin{array}{c}0.745^{* * * *} \\
(0.049)\end{array}$ & $\begin{array}{c}0.057 \\
(0.171)\end{array}$ & $\begin{array}{c}-40.460 * * * \\
(4.662)\end{array}$ & $\begin{array}{l}-0.003 \\
(0.002)\end{array}$ & $\begin{array}{r}-0.086^{* * * *} \\
(0.009)\end{array}$ & $\begin{array}{c}0.744 * * * \\
(0.049)\end{array}$ & $\begin{array}{c}0.058 \\
(0.171)\end{array}$ & $\begin{array}{c}-40.150 * * * \\
(4.660)\end{array}$ & $\begin{array}{l}-0.003 \\
(0.002)\end{array}$ \\
\hline State Ownership & $\begin{array}{c}-0.034 * * \\
(0.015)\end{array}$ & $\begin{array}{l}-0.100 \\
(0.083)\end{array}$ & $\begin{array}{c}0.070 \\
(0.294)\end{array}$ & $\begin{array}{l}-10.530 \\
(7.792)\end{array}$ & $\begin{array}{c}0.003 \\
(0.005)\end{array}$ & $\begin{array}{c}-0.035 * * \\
(0.015)\end{array}$ & $\begin{array}{l}-0.086 \\
(0.082)\end{array}$ & $\begin{array}{c}0.073 \\
(0.294)\end{array}$ & $\begin{array}{l}-11.600 \\
(7.767)\end{array}$ & $\begin{array}{c}0.003 \\
(0.005)\end{array}$ \\
\hline Firm Size & $\begin{array}{c}0.014 * * * \\
(0.002)\end{array}$ & $\begin{array}{c}-0.018 * \\
(0.011)\end{array}$ & $\begin{array}{c}0.098 * * * \\
(0.034)\end{array}$ & $\begin{array}{c}0.342 \\
(1.093)\end{array}$ & $\begin{array}{l}0.001 * \\
(0.000)\end{array}$ & $\begin{array}{c}0.014 * * * \\
(0.002)\end{array}$ & $\begin{array}{l}-0.019 * \\
(0.011)\end{array}$ & $\begin{array}{c}0.098 * * * \\
(0.034)\end{array}$ & $\begin{array}{c}0.395 \\
(1.093)\end{array}$ & $\begin{array}{l}0.001 * \\
(0.000)\end{array}$ \\
\hline Firm Age & $\begin{array}{c}-0.001^{* * *} \\
(0.000)\end{array}$ & $\begin{array}{c}0.001 \\
(0.001)\end{array}$ & $\begin{array}{l}-0.009 * \\
(0.004)\end{array}$ & $\begin{array}{c}-0.09 \\
(0.138)\end{array}$ & $\begin{array}{c}0.000 \\
(0.000)\end{array}$ & $\begin{array}{r}-0.001 * * * \\
(0.000)\end{array}$ & $\begin{array}{c}0.001 \\
(0.001)\end{array}$ & $\begin{array}{c}-0.009 * \\
(0.004)\end{array}$ & $\begin{array}{l}-0.081 \\
(0.138)\end{array}$ & $\begin{array}{c}0.000 \\
(0.000)\end{array}$ \\
\hline Constant & $\begin{array}{c}0.002 \\
(0.014)\end{array}$ & $\begin{array}{c}0.101 \\
(0.074)\end{array}$ & $\begin{array}{c}0.072 \\
(0.249)\end{array}$ & $\begin{array}{c}23.300 * * * \\
(7.336)\end{array}$ & $\begin{array}{c}-0.009 * * * \\
(0.003)\end{array}$ & $\begin{array}{c}0.006 \\
(0.014)\end{array}$ & $\begin{array}{c}0.062 \\
(0.072)\end{array}$ & $\begin{array}{c}0.070 \\
(0.253)\end{array}$ & $\begin{array}{c}26.290 * * * \\
(7.137)\end{array}$ & $\begin{array}{c}-0.008 * * * \\
(0.003)\end{array}$ \\
\hline $\begin{array}{l}\text { Firm and } \\
\text { Year Effect }\end{array}$ & Yes & Yes & Yes & Yes & Yes & Yes & Yes & Yes & Yes & Yes \\
\hline $\mathrm{N}$ & 4144 & 4145 & 3110 & 4145 & 1867 & 4144 & 4145 & 3110 & 4145 & 1867 \\
\hline $\mathrm{P}$-value for Chi2 & 0.000 & 0.000 & 0.002 & 0.000 & 0.000 & 0.000 & 0.000 & 0.003 & 0.000 & 0.000 \\
\hline
\end{tabular}

Standard errors are in parentheses. $* * *, * *$, and $*$ represent statistical significance at the $1 \%, 5 \%$, and $10 \%$ levels, respectively. 
Table 8 Changes of Performance and R\&D of Firms and the Types of VCFs

This is a series of random effect panel regressions for the profitability, sales growth, labor productivity and R\&D of FVC-backed, DVC-backed and Non-VC-backed Firms. The observations are firm-year units of the sampled 258 VC-backed firms and their non-VC-backed counterparts (1-5 pairs) matched by PSM. We use location, industry and ROE as the main matching criteria. The dependent variables include ROS, ROE, Sales Growth, Labor Productivity and R\&D expenditure over total sales. Independent variables include DVC Dummy, a dummy variable that is equal to 1 if the firm is backed by domestic VCs and is equal to 0 if otherwise; FVC Dummy, a dummy variable that is equal to 1 if the firm is backed by foreign VCs and is equal to 0 if otherwise; VC Entry, a dummy variable that is equal to 0 for the period before the investment is made and is equal to 1 for the period after the investment is made; DVC Post, which is an interaction term of DVC Dummy and VC Entry; FVC Post, which is an interaction term of FVC Dummy and VC Entry. All control variables are the same to those of Table 4.

\begin{tabular}{|c|c|c|c|c|c|}
\hline & $\begin{array}{l}(1) \\
\text { ROS }\end{array}$ & $\begin{array}{l}(2) \\
\text { ROE }\end{array}$ & $\begin{array}{c}\text { (3) } \\
\text { Sales Growth }\end{array}$ & $\begin{array}{c}(4) \\
\text { Labor Productivity }\end{array}$ & $\begin{array}{l}(5) \\
R \& D\end{array}$ \\
\hline DVC Dummy & $\begin{array}{c}0.043 * * * \\
(0.010)\end{array}$ & $\begin{array}{l}-0.031 \\
(0.047)\end{array}$ & $\begin{array}{l}0.314 * * \\
(0.147)\end{array}$ & $\begin{array}{l}25.320 * * * \\
(5.002)\end{array}$ & $\begin{array}{c}0.010 * * * \\
(0.002)\end{array}$ \\
\hline FVC Dummy & $\begin{array}{c}0.030 * * \\
(0.013)\end{array}$ & $\begin{array}{l}-0.010 \\
(0.064)\end{array}$ & $\begin{array}{l}0.352^{*} \\
(0.197)\end{array}$ & $\begin{array}{c}23.150 * * * \\
(6.772)\end{array}$ & $\begin{array}{c}0.005 * * \\
(0.002)\end{array}$ \\
\hline VC Entry & $\begin{array}{c}-0.017 * * * \\
(0.004)\end{array}$ & $\begin{array}{c}-0.074 * * * \\
(0.024)\end{array}$ & $\begin{array}{l}-0.044 \\
(0.088)\end{array}$ & $\begin{array}{l}-3.781 * \\
(2.109)\end{array}$ & $\begin{array}{c}0.001 \\
(0.001)\end{array}$ \\
\hline DVC Post & $\begin{array}{c}0.013 \\
(0.012)\end{array}$ & $\begin{array}{c}0.043 \\
(0.063)\end{array}$ & $\begin{array}{c}-0.387 * \\
(0.214)\end{array}$ & $\begin{array}{c}14.800 * * * \\
(5.551)\end{array}$ & $\begin{array}{c}0.004 \\
(0.003)\end{array}$ \\
\hline FVC Post & $\begin{array}{l}0.020^{*} \\
(0.010)\end{array}$ & $\begin{array}{l}0.119^{*} \\
(0.071)\end{array}$ & $\begin{array}{l}-0.200 \\
(0.251)\end{array}$ & $\begin{array}{c}18.020 * * * \\
(6.212)\end{array}$ & $\begin{array}{c}0.006 * * \\
(0.003)\end{array}$ \\
\hline Employee Treatment & $\begin{array}{l}0.000^{*} \\
(0.000)\end{array}$ & $\begin{array}{c}0.001 \\
(0.001)\end{array}$ & $\begin{array}{c}0.006 * * \\
(0.003\end{array}$ & $\begin{array}{c}1.122 * * * \\
(0.070)\end{array}$ & $\begin{array}{c}0.000 * * * \\
(0.000)\end{array}$ \\
\hline Leverage & $\begin{array}{c}-0.080 * * * \\
(0.009)\end{array}$ & $\begin{array}{c}0.760 * * * \\
(0.050)\end{array}$ & $\begin{array}{c}0.040 \\
(0.175)\end{array}$ & $\begin{array}{c}-38.360 * * * \\
(4.641)\end{array}$ & $\begin{array}{l}-0.002 \\
(0.002)\end{array}$ \\
\hline State Ownership & $\begin{array}{c}-0.031 * * \\
(0.014)\end{array}$ & $\begin{array}{l}-0.081 \\
(0.084)\end{array}$ & $\begin{array}{c}0.149 \\
(0.297)\end{array}$ & $\begin{array}{c}-10.640 \\
(7.679)\end{array}$ & $\begin{array}{c}0.001 \\
(0.005)\end{array}$ \\
\hline Firm Size & $\begin{array}{c}0.011 * * * \\
(0.002)\end{array}$ & $\begin{array}{l}-0.019 * \\
(0.012)\end{array}$ & $\begin{array}{c}0.079 * * \\
(0.037)\end{array}$ & $\begin{array}{l}-1.149 \\
(1.140)\end{array}$ & $\begin{array}{l}-0.000 \\
(0.000)\end{array}$ \\
\hline Firm Age & $\begin{array}{c}-0.001 * * \\
(0.000)\end{array}$ & $\begin{array}{c}0.001 \\
(0.001)\end{array}$ & $\begin{array}{c}-0.008 * \\
(0.005)\end{array}$ & $\begin{array}{c}-0.031 \\
(0.136)\end{array}$ & $\begin{array}{c}0.000 \\
(0.000)\end{array}$ \\
\hline Constant & $\begin{array}{c}0.025 * * \\
(0.012)\end{array}$ & $\begin{array}{c}0.014 \\
(0.065)\end{array}$ & $\begin{array}{l}-0.031 \\
(0.220)\end{array}$ & $\begin{array}{c}31.150 * * * \\
(6.444)\end{array}$ & $\begin{array}{c}0.002 \\
(0.002)\end{array}$ \\
\hline Firm and Year Effect & Yes & Yes & Yes & Yes & Yes \\
\hline $\mathrm{N}$ & 3999 & 4000 & 2997 & 4000 & 1789 \\
\hline $\mathrm{P}$-value for Chi2 & 0.000 & 0.000 & 0.002 & 0.000 & 0.000 \\
\hline
\end{tabular}

Standard errors are in parentheses. $* * *, * *$, and $*$ represent statistical significance at the $1 \%, 5 \%$, and $10 \%$ levels, respectively. 
Table 9 Changes of Performance and R\&D of Firms and Syndicated Venture Investment

This is a series of random effect panel regressions for the profitability, sales growth, labor productivity and R\&D of firms backed by syndicated venture investment, non-syndicated investment and non-VC backed firms. The observations are firm-year units of the sampled 258 VC-backed firms and their non-VC-backed counterparts (1-5 pairs) matched by PSM. We use location, industry and ROE as the main matching criteria. The dependent variables include ROS, ROE, Sales Growth, Labor Productivity and R\&D expenditure over total sales. Independent variables include Syndication, a dummy variable that is equal to 1 if the firm is backed by syndicated venture investment and is equal to 0 if otherwise; Non-Syndication, a dummy variable that is equal to 1 if the firm is backed non-syndicated venture investment and is equal to 0 if otherwise; VC Entry, a dummy variable that is equal to 0 for the period before the investment is made and is equal to 1 for the period after the investment is made; Syn-Post Post, which is an interaction term of Syndication and VC Entry; Non-Syn-Post, which is an interaction term of Non-Syndication and VC Entry. All control variables are the same to those of Table 4.

\begin{tabular}{|c|c|c|c|c|c|}
\hline & $\begin{array}{l}(1) \\
\text { ROS }\end{array}$ & $\begin{array}{c}\text { (2) } \\
\text { ROE }\end{array}$ & $\begin{array}{c}\text { (3) } \\
\text { Sales Growth }\end{array}$ & $\begin{array}{c}(4) \\
\text { Labor Productivity }\end{array}$ & $\begin{array}{c}(5) \\
R \& D\end{array}$ \\
\hline \multirow[t]{2}{*}{ Non-Syndication } & $0.034 * * *$ & -0.038 & $0.274 *$ & $32.220 * * *$ & $0.008 * * *$ \\
\hline & $(0.011)$ & $(0.054)$ & $(0.167)$ & $(5.643)$ & $(0.002)$ \\
\hline \multirow[t]{2}{*}{ Syndication } & $0.034 * *$ & -0.002 & $0.408^{*}$ & $24.370 * * *$ & $0.006 * * *$ \\
\hline & $(0.014)$ & $(0.068)$ & $(0.215)$ & $(7.127)$ & $(0.002)$ \\
\hline \multirow[t]{2}{*}{ VC Entry } & $-0.016 * * *$ & $-0.073 * * *$ & -0.050 & -3.018 & 0.001 \\
\hline & $(0.004)$ & $(0.024)$ & $(0.087)$ & $(2.075)$ & $(0.001)$ \\
\hline \multirow[t]{2}{*}{ Non-Syn-Post } & 0.002 & -0.049 & -0.284 & 4.125 & 0.003 \\
\hline & $(0.011)$ & $(0.066)$ & $(0.224)$ & $(5.747)$ & $(0.003)$ \\
\hline \multirow[t]{2}{*}{ Syn-Post } & $0.066 * * *$ & $0.137 *$ & -0.312 & $12.950 *$ & $0.008 * * *$ \\
\hline & $(0.014)$ & $(0.081)$ & $(0.286)$ & $(7.068)$ & $(0.003)$ \\
\hline \multirow[t]{2}{*}{ Employee Treatment } & $0.000^{*}$ & 0.001 & $0.007 * *$ & $0.957 * * *$ & $0.000 * * *$ \\
\hline & $(0.000)$ & $(0.001)$ & $(0.003)$ & $(0.072)$ & $(0.000)$ \\
\hline \multirow[t]{2}{*}{ Leverage } & $-0.078 * * *$ & $0.739 * * *$ & 0.126 & $-37.280 * * *$ & 0.000 \\
\hline & $(0.009)$ & $(0.051)$ & $(0.181)$ & $(4.695)$ & $(0.002)$ \\
\hline \multirow[t]{2}{*}{ State Ownership } & $-0.040 * * *$ & -0.069 & 0.185 & -7.491 & 0.000 \\
\hline & $(0.015)$ & $(0.084)$ & $(0.299)$ & $(7.581)$ & $(0.004)$ \\
\hline \multirow[t]{2}{*}{ Firm Size } & $0.009 * * *$ & -0.019 & 0.057 & $-3.492 * * *$ & 0.000 \\
\hline & $(0.002)$ & $(0.012)$ & $(0.038)$ & $(1.161)$ & $(0.000)$ \\
\hline \multirow[t]{2}{*}{ Firm Age } & $-0.000 *$ & 0.001 & -0.007 & -0.013 & 0.000 \\
\hline & $(0.000)$ & $(0.001)$ & $(0.005)$ & $(0.137)$ & $(0.000)$ \\
\hline \multirow[t]{2}{*}{ Constant } & $0.036 * * *$ & 0.030 & 0.014 & $44.140 * * *$ & 0.000 \\
\hline & $(0.013)$ & $(0.067)$ & $(0.226)$ & $(6.524)$ & $(0.002)$ \\
\hline Firm and Year Effect & Yes & Yes & Yes & Yes & Yes \\
\hline $\mathrm{N}$ & 3766 & 3767 & 2819 & 3767 & 1639 \\
\hline $\mathrm{P}$-value for Chi2 & 0.000 & 0.000 & 0.012 & 0.000 & 0.000 \\
\hline
\end{tabular}

Standard errors are in parentheses. $* * *, * *$, and $*$ represent statistical significance at the $1 \%, 5 \%$, and $10 \%$ levels, respectively. 